Volume 7, Issue 1 (Winter 2015)

\title{
Dutch Batavia: Exposing the Hierarchy of the Dutch Colonial City
}

Marsely L. Kehoe

marselykehoe@gmail.com

Recommended Citation:

Kehoe, Marsely L. "Dutch Batavia: Exposing the Hierarchy of the Dutch Colonial City," JHNA 7.1 (Winter 2015). doi: 10.5092/jhna.2015.7.1.3

Available at https://jhna.org/articles/dutch-batavia-exposing-hierarchy-dutch-colonial-city/

Published by Historians of Netherlandish Art: https://hnanews.org/

Republication Guidelines: https://jhna.org/republication-guidelines/

Notes: This PDF is provided for reference purposes only and may not contain all the functionality or features of the original, online publication. This is a revised PDF that may contain different page numbers from the previous version. Use electronic searching to locate passages. This PDF provides paragraph numbers as well as page numbers for citation purposes.

ISSN: 1949-9833 


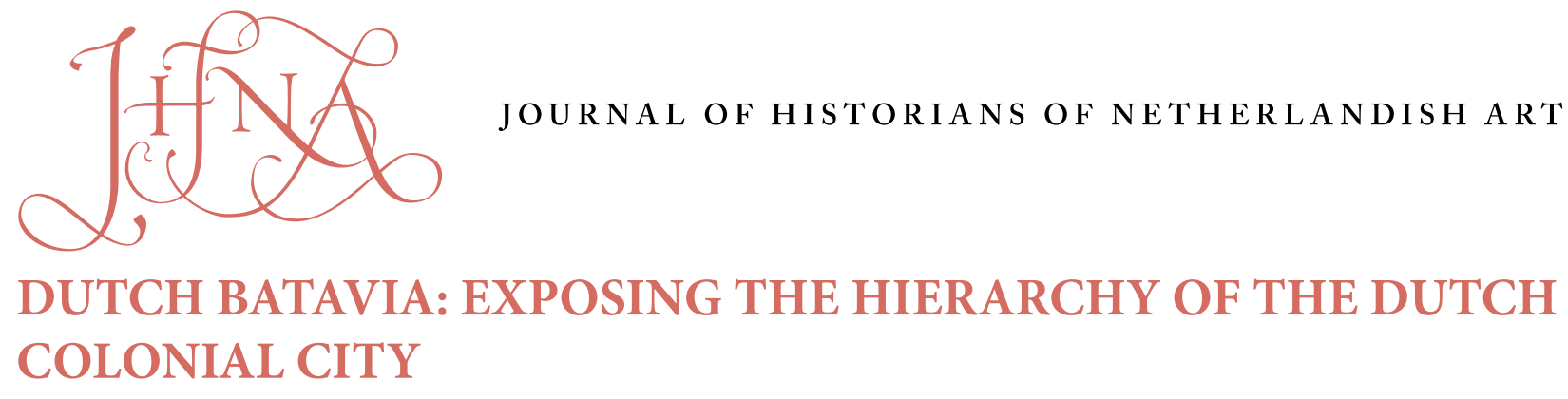

\section{Marsely L. Kehoe}

The built environment was an important determinant of social behavior, particularly segregation, in the colonial city of Batavia. Built in 1619 to establish a Dutch administrative and cultural headquarters in Southeast Asia for the Dutch East India Company (VOC), Batavia evinced the general principles of seventeenth-century Dutch planning back in the Netherlands, including a layout that imposed order on the city's diverse population. But Batavia accomplished this order even more stringently, structuring it to secure Dutch domination. To further reinforce this control, VOC administrators were eager for Dutch citizens to express a cohesive Dutch identity. Despite this desire, Dutch Batavians developed ostentatious displays of rank through costume and behavior, which provoked a series of sumptuary codes. This preoccupation with rank among the Dutch populace signaled the same hierarchy within the social fabric of Batavia that was encoded in the very form of this planned city. DOI: 10.5092/jhna.2015.7.1.3

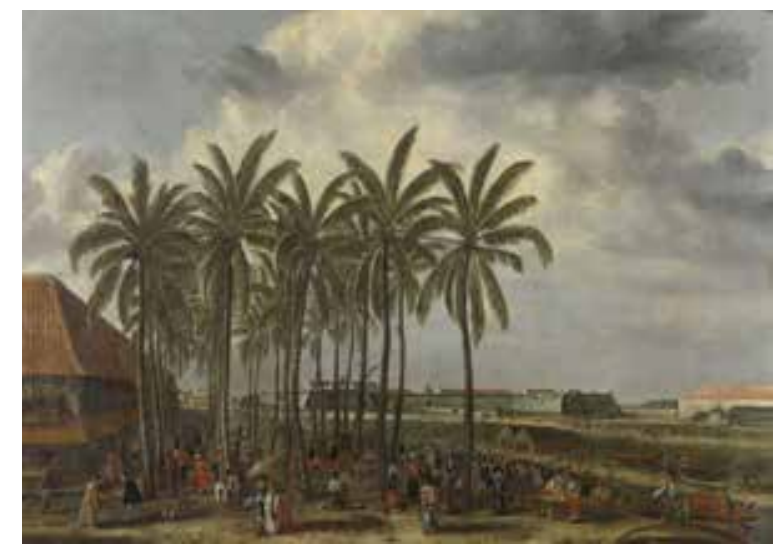

Fig. 1 Andries Beeckman, The Castle of Batavia, 1661 , oil on canvas, $108 \times 151.5 \mathrm{~cm}$. Rijksmuseum, Amsterdam, inv. no. SK-A-19 (Photo: Rijksmuseum, Amsterdam) (artwork in the public domain)

$\mathrm{I}$ $\mathrm{n}$ the foreground of Andries Beeckman's The Castle of Batavia (1661, fig. 1), a merchant in European attire strolls through a marketplace with his Eurasian wife on his arm, as a small servant struggles to hold a parasol above their heads. This parasol was meant on the one hand to protect them from the harsh tropical sunlight, and on the other to function as a status symbol, an aspect underscored by the presence of the servant. In 1647, such markers of status had been outlawed for all but the very highest-ranking Dutch East India Company (VOC) officers, namely the governor-general and his council--others could only use a parasol if holding it themselves. ${ }^{1}$ Dutch Batavians, however, much like the merchant in Beeckman's painting, continued to display their wealth and status through ostentatious dress and behavior, thus muddling the expression 
of proper social rank. High-ranking VOC officials and later observers considered this behavior very un-Dutch. Such displays violated social decorum and undermined the cohesion of what was already a worryingly small minority Dutch population among the city's diverse ethnicities. This paper will argue that the VOC administration actually preferred the subtler reinforcement of Dutch control that could be achieved through the hierarchical structure of this colonial city's built environment.

The Dutch citizens of Batavia were a small group, overwhelmed by the larger Chinese, Indian, Indonesian, and enslaved populations. In order to dominate these groups, the Dutch Batavians faced contradictory demands: to appear as a cohesive and culturally Dutch group, intent, in theory, on avoiding ostentatious displays of status, yet keen to exert their dominance over the other groups. This tension led in practice to showy displays of status through costume, behavior, and the accumulation of large retinues of personal slaves. ${ }^{2}$ These displays included the adoption of local symbols, like the parasol, in addition to practices more familiar to a European population, like the wearing of fine textiles and jewelry and the outfitting of carriages. Various governors-general of the Dutch East Indies introduced sumptuary codes during the company period (1619-1795) in attempts to regulate this behavior.

3 For the most part, these codes allowed only the very top of Dutch Batavian society, the governor-general and his family, and later some high-ranking officers, to display its status. The remaining Dutch population was denied the major markings of prestige, in essence flattening the hierarchy within the Dutch population, and in theory leading to more social cohesion. The very need for these laws, and their repetition and reissuance, demonstrate that the Dutch Batavians were constantly violating these ordinances, acting above their status and outside of Dutch social norms. $^{3}$

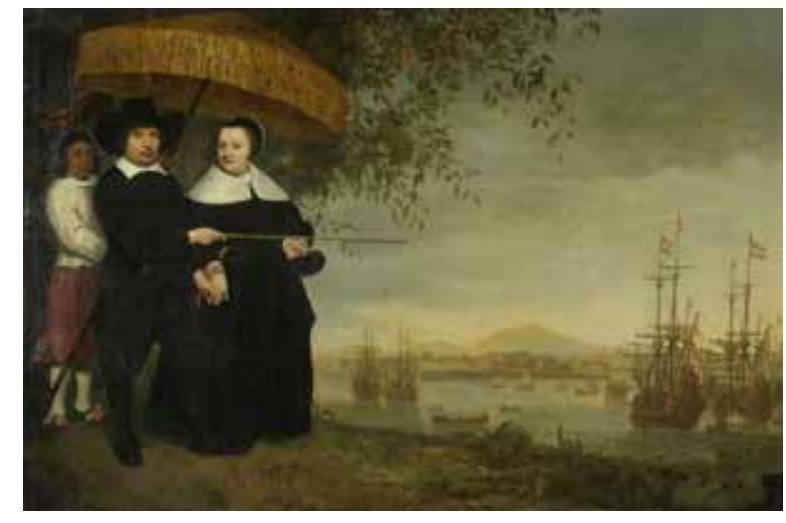

Fig. 2 Aelbert Cuyp, The Commander of the Homeward-Bound Fleet, ca. 1640-60, oil on canvas, $138 \times 208 \mathrm{~cm}$. Amsterdam, Rijksmuseum, inv. no. SK-A-2350 (Photo: Rijksmuseum, Amsterdam) (artwork in the public domain)

Aelbert Cuyp's The Commander of the Homeward-Bound Fleet, painted between 1640 and 1660, shows a Dutch commander, probably Jakob Martensen, and his wife, standing on a rise with a view of the harbor of Batavia with the fort at center background (fig. 2). ${ }^{4}$ This couple's sober dress befits Dutch expectations of propriety better than Beeckman's supercilious merchant, but even here the couple violates the 1647 rule outlawing the servant-held parasol. The appearance of the parasol in this commissioned portrait functioned as a Batavian marker of superiority. Regardless of whether Martensen and his wife had actually walked along Batavia's canals with such a servant in tow, apparently they wanted to be depicted doing just that in order to outwardly assert their 
dominance with an element of local color.

5 A third example of a painting that defied traditional Dutch social decorum depicts senior merchant Pieter Cnoll, who in 1665 commissioned a family portrait of himself and his wife, their two daughters, and two servants (fig. 3). ${ }^{5}$ The forthcoming 1680 code would outlaw the finery paraded here: the women's pearls and Pieter's gold buttons and buckles. ${ }^{6}$ The presence of the servants also signals Cnoll's high status, though they represent only a small number of the fifty slaves he owned. In 1754, the most expansive set of laws, the "Measures for Curbing Pomp and Circumstance," established standards ranging from the costuming of coach horses to the types of cushions that could be used in a coach for a funeral procession. ${ }^{7}$ This code also established a range of fines for violation of the rules: the lower one's class and ethnic status, the higher the fine.

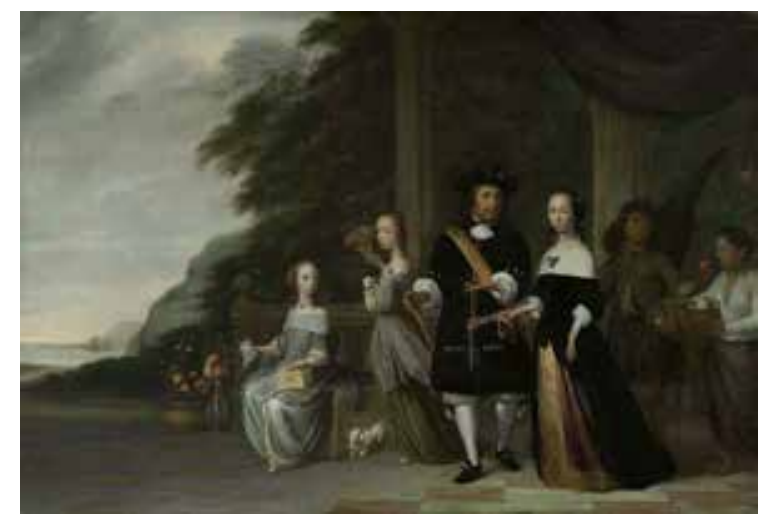

Fig. 3 Jacob Coeman, The Batavian Senior Merchant Pieter Cnoll, His Eurasian Wife and Daughters and Domestic Slaves, 1665, oil on canvas, 130 x 190.5 cm. Amsterdam, Rijksmuseum, inv. no. SK-A-4062 (Photo: Rijksmuseum, Amsterdam) (artwork in the public domain)

Jean Gelman Taylor writes about these codes in her volume about social relationships in eighteenth-century Batavia, declaring the 1680 codes to be about "bring[ing] practice into line with Dutch habits, while the other [1754 codes] marks a colony that had renounced the pretense of being Dutch in spirit." 8 I maintain that the behavior that prompted the establishment of sumptuary codes was considered problematic not for being un-Dutch, but for exposing the hierarchical nature of Batavian society. While some manifestations of this prestige were borrowed from the local population, the preoccupation of Dutch Batavians with social position and trappings of prestige is not unique to this colonial environment. Instead, Batavia reveals the hierarchies inherent in Dutch society both at home and abroad in the seventeenth century.

Some of the performance of status as it related to local practice--like the parasol--was common in colonial societies. ${ }^{9}$ The co-opting of local symbols proved effective both for asserting dominance and complicating the colonizer's outsider role. Colonizers shared the same anxieties about maintaining control as the indigenous rulers who exhibited the same ritualistic forms of display--only more so, given their tenuous status within the larger population of Batavia and throughout the East Indies. ${ }^{10}$ The very assertion of dominance led to discomfort for Dutch colonizers, and, I contend, the Dutch way of enforcing hierarchy was thus to conceal their dominance so that social divisions appeared to develop unconsciously rather than through overt regulation. Instead, the built environment of Batavia was meant to do the work of shaping the city's diverse population into a hierarchy that served colonial needs. This desire to avoid obvious signs of dominance contributed to the undeserved reputation of the Dutch in the VOC period as being just traders, not colonists, in opposition to the other European colonial powers. ${ }^{11}$ 
The very form of Batavia, which was built following certain seventeenth-century Dutch urban planning principals, served the interests of the VOC by arranging Batavian society into a hierarchy headed by the Dutch. This city, filled with Dutch-style buildings (visible in the backgrounds of Beeckman's and Cuyp's paintings), provided a recognizable and reassuring statement of Dutch identity for the top segment of Batavian society, which, while unified, could dominate the remaining population (figs. 1 and 2; see also figs. 9 and 10). Concealed in the Dutch gridded plan are the barriers to movement that organized the Batavians into distinct ethnic groups, with varying levels of access within the city. The remainder of this paper focuses on the built environment as an important determinant of social behavior, particularly segregation, in the colonial city.

9 Segregation was codified by Batavia's very form: the city's plan separated populations with unbridged canals and city walls. My thesis builds on the work of scholars of the colonial built environment, such as Swati Chattopadhyay and Brenda Yeoh, who elucidate the segregation of Calcutta and Singapore, respectively. ${ }^{12}$ These authors look at how colonists and the colonized functioned within these already-built cities to create and reinforce colonial social stratification. Batavia is different from these two cities in that its architecture and layout in themselves enacted this segregation. Examining Batavia's plan and its relationship to seventeenth-century Dutch planning principles, I argue that it is misleading to understand Batavia, as some scholars have, as representing a pragmatic and egalitarian order that was later corrupted by the colonial situation. In fact, the social stratification and segregation of Batavia derived in certain ways directly from its Dutch plan.

\section{The Dutch East India Company}

10 The Dutch East India Company founded the city of Batavia in 1619, marking their increasing domination of Europe's burgeoning global trade after only two decades of involvement. ${ }^{13}$ Fifteenth-century efforts by Portuguese mariners had expanded Europeans' knowledge of the world's oceans and throughout the sixteenth century Spain and Portugal established routes and made claims to many world markets. The main interest of the Spanish and Portuguese was in developing an overseas route to the East, bypassing the overland routes that were dominated by Middle Eastern merchants, in order to access cloves, nutmeg, cinnamon, and pepper at the source, so they could cheaply supply the growing European market for these spices. The source of these spices was the aptly named the Spice Islands, now called Maluku or the Moluccas, today part of Indonesia. ${ }^{14}$

11 The Dutch Republic, newly formed in 1579, and having declared its independence from Spain in 1581 , took the fight for independence to the theater of world trade. Not content to distribute the goods Spain and Portugal were importing to the markets of Europe, the Dutch wanted to go to the sources themselves, to beat out their European competitors. In the last decade of the sixteenth century, the Dutch made great strides in world navigation, beginning with the efforts of Jan Huygen van Linschoten (1533-1611) and Cornelis de Houtman (ca. 1565-1599), who financed and organized trading voyages. ${ }^{15}$ In response to the success of these private trading efforts, and with the foresight that competition among Dutch merchants would keep prices high at the source and low at their destination, the Dutch market, in 1602 the Dutch government formed the Dutch East India Company (Verenigde Oost-Indische Compagnie). The VOC unified (verenigd) the 
earlier private efforts. It was given a monopoly over Dutch-Asian trade (prohibiting private Dutch merchants from trading), with the right to use military means, including the deployment of the Republic's soldiers, and to negotiate treaties with local leaders. To increase demand, retain high profits, and ensure a steady supply of spices, the Dutch knew they had to control all aspects of the market from the source to Europe's tables. The monopoly fostered by the Dutch East India Company helped the Dutch to control the European market.

12 In the Spice Islands, the VOC's methods varied: their interest was not in territorial acquisition but in domination of trade. The company set up outposts and warehouses in key locations and developed exclusive trade relationships with local merchants. In some cases VOC officers massacred or enslaved local producers, introducing Dutch settlers in their place; they destroyed spice trees growing outside of the Dutch controlled areas; and VOC employees notoriously tortured and killed twenty English East-India Company (EIC) traders in 1623 in Amboina to consolidate their monopoly. ${ }^{16}$ While chartered as a privately financed trading company, the VOC represented the Dutch Republic economically and militarily throughout Africa and Asia. The ultimate goal of the VOC was to secure a Dutch foothold in Asian trade. The immediate project, however, was to break the Portuguese dominance of the Indonesian archipelago's Spice Islands.

13 The founding of Batavia on the island of Java was key to the success of the VOC. This would have lasting consequences in the region, as it would remain the capital of the colonial Dutch East Indies into the nineteenth and twentieth centuries--becoming Jakarta, the capital of Indonesia, after independence. In 1618, the new governor-general of the VOC, Jan Pietersz Coen (1587-1629; governor-general 1618-23 and 1627-29), chose a location and initiated a series of events that led to the establishment of the city of Batavia. Coen recognized the need for an eastern capital for the VOC, which would serve as an administrative center and warehouse, where goods could be collected and shipped back to Europe. The VOC realized an administrative center in the archipelago would make for more efficient administration of trade. At this point, the VOC was not interested in acquiring territory beyond a secure location for a harbor, town, and fort. It was only after the dissolution of the VOC two centuries later and the beginning of formal governmental colonization that more land would be required for plantation farming. Coen chose as his site an inhabited harbor on the northern coast of Java, one of the larger islands. Controlling this location allowed the Dutch to bypass the contested Strait of Malacca and to control traffic passing through the Sunda Strait. As had been discovered by Indonesians long before the arrival of Europeans, the mouth of the Ciliwung River, with its easy access to the inland area and a supply of fresh water, was an ideal location for a harbor.

14 The site already boasted a centuries-old city, Jayakarta (from which the modern city derives its name), a trading center within the archipelago, inhabited by locals as well as Arab, Chinese, Portuguese, and English merchants. ${ }^{17}$ With permission from the local ruler, the Dutch had established a fort in Jayakarta. Exploiting the political instabilities of the region, Coen was able to easily take over the city in May of $1619 .{ }^{18}$ After razing Jayakarta, Coen wanted to name the new VOC city "New Hoorn" after his birthplace, but the VOC overruled him and made the name Batavia official. ${ }^{19}$ The naming of this city was an important step in marking the region as Dutch--"Batavia" was the ancient Latin name for a tribe in the region of the Netherlands and the history of the Batavians is an important founding myth in the Dutch collective identity. ${ }^{20}$ 
15 Beginning in the 1660s, a number of factors combined that would cause a slow decline in the fortunes of the VOC, which ultimately resulted in bankruptcy at the close of the eighteenth century. ${ }^{21}$ These factors included a shift in European tastes, a decline in profitability, less access to the staples of the spice trade, namely pepper, and a decline in the Asian supply of precious metals to the VOC. ${ }^{22}$ Health problems in the city of Batavia contributed to growing personnel costs, as more and more of the soldiers and company employees arriving in the city succumbed to malaria and needed to be replaced. ${ }^{23}$ In the nineteenth and twentieth centuries, the Dutch government took over administration from the VOC, officially colonizing the region.

\section{The Plan of Batavia}

16 My analysis of the city of Batavia focuses on the historic core of the city, as indicated in the backgrounds of figures 1 and 2. This core was established in 1619 and completed as a walled city with numerous canals by the middle of the century. While city maps provide data for my exploration of the form of the city, this evidence requires caution, as cartography is not simply an objective rendering of space. ${ }^{24}$ For example, the 1681 map explored in detail here (fig. 4) is a close copy of a 1650 original, which fails to note a major population shift of slaves to a quarter just south of the city walls in 1664 . That the newer map was not updated to reflect the change may indicate a
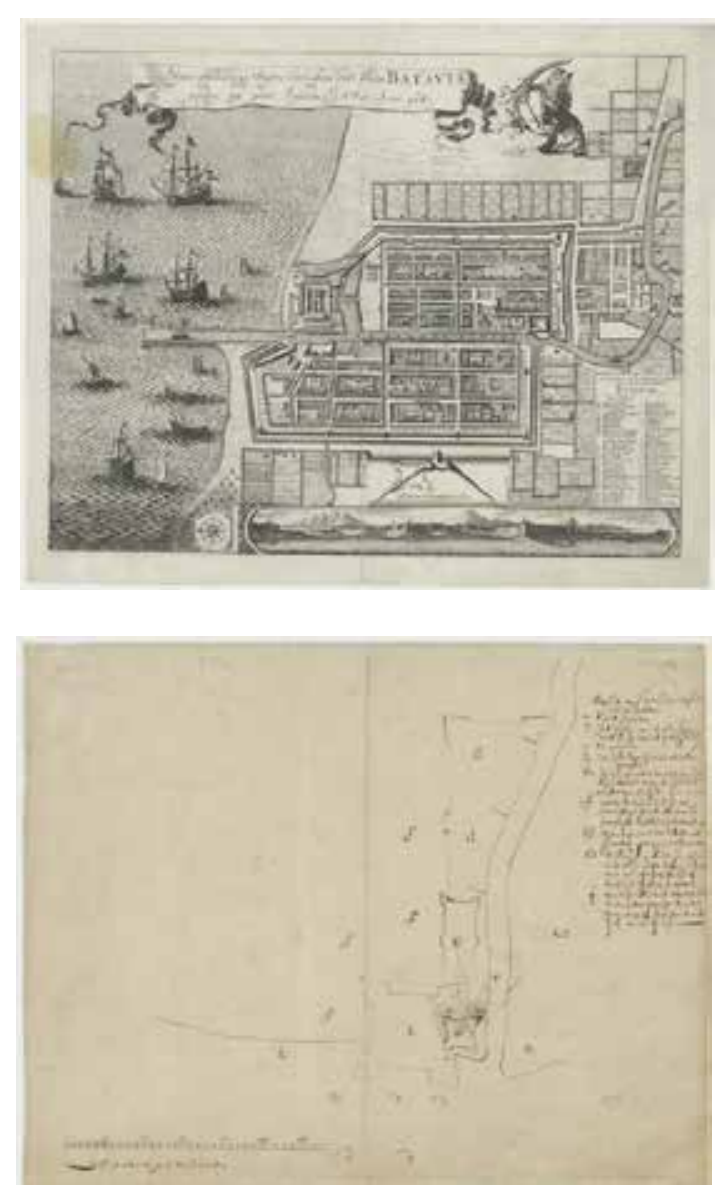

Fig. 5 Plan van 't fort en omleggende land Jacatra, 1619. Nationaal Archief, The Hague, Kaartcollectie Buitenland Leupe, 4.VEL 1176 (artwork in the public domain)
Fig. 4 Waere affbeeldinge Wegens het Casteel ende Stadt Batavia, 1681. Nationaal Archief, The Hague, VELH 430 (artwork in the public domain)

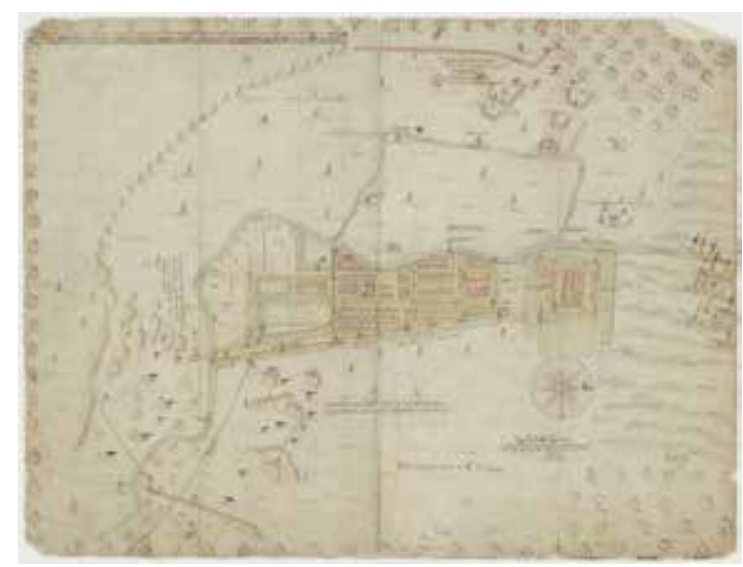

Fig. 6 Jacob Cornelisz Cuyck, Plan of Batavia, 1629 (copy by Hessel Gerritsz, 1630). Nationaal Archief, The Hague, Kaartcollectie Buitenland Leupe, 4.VEL 1179B (artwork in the public domain) 
disregard for the enslaved population. ${ }^{25}$ It is also misleadingly titled "true image of the castle and city Batavia on Java," despite being outdated.

17 Before the VOC gained control of the area, all VOC residences and warehouses had been located within the previously established fort, Kasteel Batavia. An early map of 1619 shows the location and arrangement of the fort, plans for its potential expansion, and a possible city location (fig. 5 ). The first half of the city stretched south from the fort along the eastern bank of the river, with clearly plotted rectilinear blocks (fig. 6). ${ }^{26}$ By 1650 the city had taken on its core appearance--the river had been straightened and the walls, completed in 1645, surrounded a roughly rectangular area straddling the river--this is the historical center of the city of Batavia, now called the kota in Jakarta (see fig. 4). ${ }^{27}$

18 My analysis focuses on this 1681 map, multiple copies of which remain in libraries and special collections, and which is itself a close copy of a 1650 original by Clement de Jonghe: its regular reproduction in different formats and languages suggests a wide perception that this map was highly representative of Batavia. ${ }^{28}$ This map shows the complete walled city in detail, along with the beginnings of expansion outside the walls. ${ }^{29}$ The placement of walls, streets, canals, and bridges in an eighteenth-century map, representing a 1770 survey, is consistent with the one from 1681, suggesting that these maps represent the actual built environment of Batavia (fig. 7). A com parison of these two maps also shows that there was very little alteration to the city's form in the ninety years between their respective creations. Expansion beyond the walls continued over the following centuries, and in the early nineteenth century the walls and fort were demolished. ${ }^{30}$

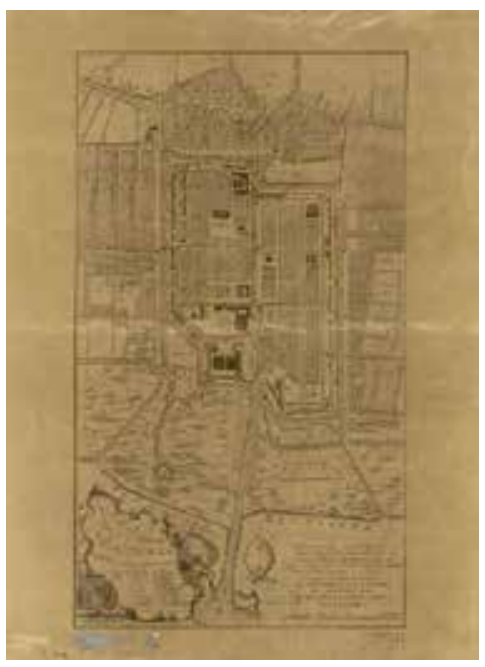

Figure 7. Plan der Stad en 't Kasteel Batavia (made under the direction of P. A. van der Parra in 1770, printed in Amsterdam by Petrus Conradi in 1780). Leiden University Library (KITLV Digital Image Library, image code DE 21,9 @ i) (artwork in the public domain)

The city plan in the 1681 and 1770 maps is rectangular, divided in two longitudinally by the straightened Ciliwung River, here called the Groote Rivier (Large River). These two halves are offset, apparently because of the uneven coastline and the situation of the fort. Within the walls, the city blocks are separated by streets and canals that run on a grid, the only exception to perfect right angles being the area of the city directly west of the fort. The city wall has regular bastions and is protected by an outer canal. The fort also has water surrounding it. The historic city seems to have been plotted by extending the lines of the fort, so that the grid is aligned along a basically 
north-south axis, rather than being related to the diagonal shoreline. The diagonal jog of the northwest corner of the city seems to have been designed to add a level of protection for the fort and visibility over more of the harbor. The relation of the bastions to the grid in the western half of the city seems to have been more consciously planned than the position of their older counterparts--there are fewer of them and presumably they were more effective, with each aligned with a road or canal to provide efficient provisioning. ${ }^{31}$ This half of the city plan also provides nearly every road and block division with a canal, while the older half has more roads and smaller blocks that lack canals, differences that enabled varying levels of access to foot and water traffic.

\section{A Dutch City in the Tropics}

20 Founded by the VOC over the ruins of Jayakarta, Batavia was built as a Dutch colonial city, and remained under Dutch control for over three centuries. The ownership of the city was apparent in part because of Batavia's important role in the VOC network, and additionally because aspects of the built environment consciously evoked the cities of the Dutch Republic. This occurred both through the diffusion of building forms and materials and through the imposition of Dutch city planning principles on the Southeast Asian landscape. The city was widely perceived to be Dutch, despite company ownership and a very diverse population, as is apparent in travelers' accounts of the city and abbreviated visual descriptions of the city. Batavia's canals, Dutch-style vernacular architecture, and grid plan augmented the association of the metropole with the periphery. For many Dutch Batavians, inhabiting a Dutch city in the tropics was a way to remain connected with the Republic, shoring up a Dutch collective identity. For other residents of the city, it was a reminder of the dominance of the Dutch social group.

21 The canals of historic Batavia, used for drainage, transportation, and protection, strike one immediately as typically Dutch. Canals are a Dutch specialty, still present across the Netherlands today. They functioned as a means of draining the Low Countries, much of which lies below sea level, in order to carve out more usable land for building and agriculture. The familiarity of the low-lying land around the port of Jayakarta likely attracted the VOC, which decided to continue the Dutch fight against water in the colonies, though not as successfully as at home. Proper Dutch canals regularly flush their contents out to the larger body of water. Batavia's canals, however, became less functional over time because of irregular water flow from inland, leading to canals with shallow, stagnant water that were unable to flush the city's sewage into the sea. In his account Oud en nieuw Oost-Indiën (1724-26), François Valentijn mentioned periodic silting due to monsoons and disruptions caused by earthquakes, which also contributed to the extension of the coastline farther into the harbor. ${ }^{32}$ The canals smelled terrible, and the residents of Batavia blamed this stinky air for the incidence of disease. Even though the climates in the Netherlands and the Indonesian archipelago differ greatly, this was not considered when the city was planned--the Dutch designers mistakenly presumed their model would function throughout the world. Despite these shortcomings, most of Batavia's canals were retained throughout the VOC period rather than being replaced with more successful and healthful alternatives.

22 When in their best condition, the canals of Batavia were more attractive than the canals at home in the Republic. Long and straight, the city's canals were lined on either side with trees and roads, enabling more efficient and pleasant transportation. The most celebrated of these canals was the Tijgersgracht (Tiger's Canal), the southern half of the canal that bisected the older eastern half 
of the city. Many of the canals in the Republic were narrower and curving, built around existing structures, while in Batavia the canals were planned from the inception of the city and forced to follow the city's grid. Johannes Nieuhof, who visited and lived in Batavia in the 1650s and 1660s, as well as the previously mentioned eighteenth-century visitor François Valentijn included in their descriptions special mention of the straightness of the streets, suggesting that this distinguished the city. ${ }^{33}$ While grids are evident in many Dutch urban plans, these authors' observations underscore that visitors found the rectilinear shape of this city notable. The city's basic rectangular gridded shape, its walls and canals, form the basis of an abbreviated image of Batavia on a French map of the north coast of Java of 1720 (fig. 8). Here, Batavia is a square, one corner of which is dedicated to the fort, with a roadstead enabling the passage of ships through the harbor, which by then was partially silted up. This much-simplified diagram of the city suggests that the draftsman recognized these traits as characteristic and essential for his represention.
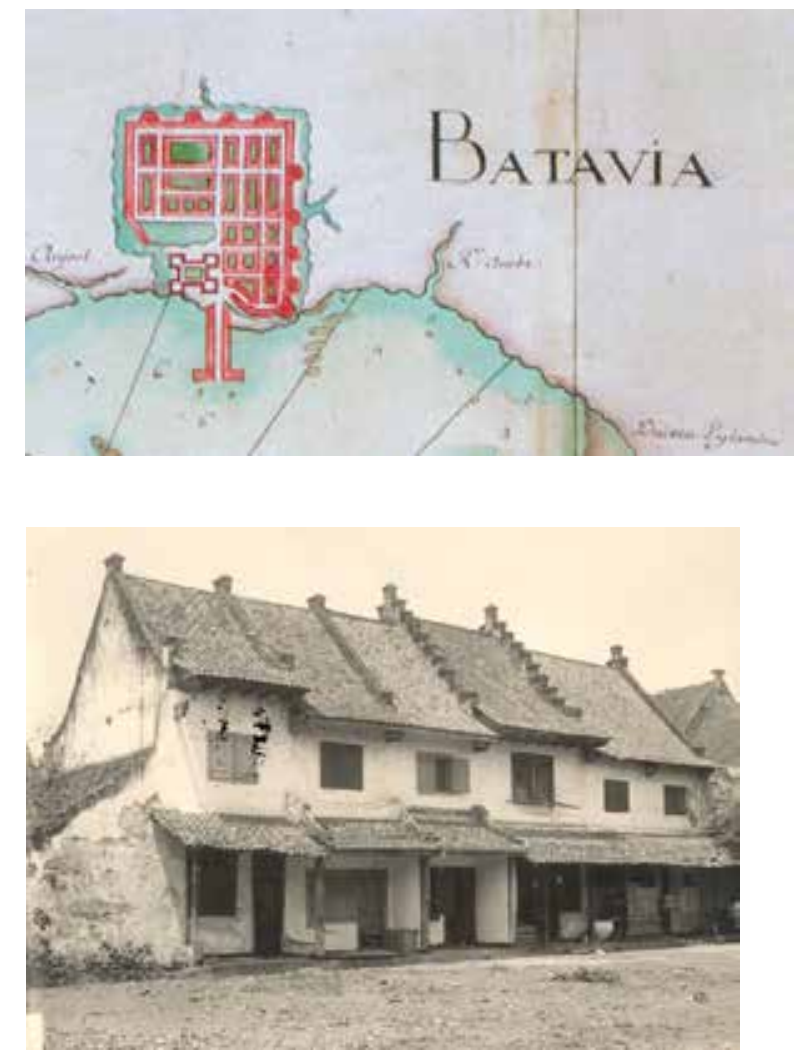

Fig. 9 Seventeenth-century houses in Batavia, ca. 1920, photograph. Leiden University Library (KITLV Digital Image Library, image code 88693) (artwork in the public domain)
Fig. 8 Carte de l'isle de lava ou sont les villes de Batauia et Bantam, (detail), ca. 1720, watercolor. Newberry Library, Chicago, VAULT drawer Ayer MS map 30 sheet 47 (NLO) (Photo: courtesy of Newberry Library) (artwork in the public domain)

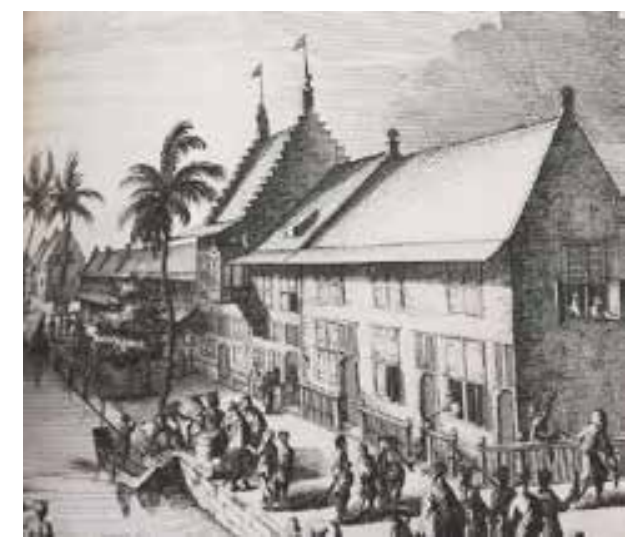

Fig. 10 Johannes Nieuhof, Tijgersgracht (detail), 1682. From Johannes Nieuhof, Gedenkwaardige Brasiliaense zee- en landreis (Amsterdam: Widow of van Jacob van Meurs, 1682). Columbia University Libraries (Photo by author) (artwork in the public domain)

23 In addition to the city's canals and its rectilinear grid, the buildings that filled it contributed to the experience of the city as Dutch for residents and visitors alike. While public buildings, such as the city hall (Stadhuis), were built in a stripped down neoclassical form, the vernacular architecture of the city recalled the domestic architecture of the home country. Few of these buildings remain, though some evidence exists in the form of early twentieth-century photographs (fig. 9). As in the cities of the Republic, residential plots in Batavia were deep and not wide, with narrow street facades and step- and spout-gabled rooflines. ${ }^{34}$ Diffusing these building forms into a tropical 
climate required a major shift to accommodate the more extreme sun and rainfall: rotating the gable ninety degrees created a deep overhang across the facade, which provided shade and deflected rain from the building's walls. ${ }^{35}$ Dutch builders may have drawn inspiration from Javanese indigenous architecture, as some local forms share this feature of a projecting roofline. ${ }^{36}$ The steep roofs and step- and spout-gables were retained, providing a recognizably Dutch visual marker, though here the gables awkwardly protrude from roofs and serve to indicate dividing walls. These can clearly be seen in engravings of the city reproduced in Nieuhof's Gedenkwaardige Brasiliaense zee- en landreis (fig. 10). ${ }^{37}$ Some local building materials were used in the construction of these houses, but it has often been noted that the bricks, rather than being produced locally, arrived in Batavia from the Republic as ballast in ships. ${ }^{38}$

24 A further indication of how those who had never visited Batavia perceived the city can been seen in vague cityscapes, as in the background of Aelbert Cuyp's double portrait of 1640-50 (see fig. 2). This painting, of course, cannot be used as evidence of an authentic view of the city, as it was painted in the Netherlands rather than on site, and an accurate view of the city was never the painter's aim. The couple stands in front of the harbor of Batavia with the city in the background. Although Cuyp had little access to visual descriptions of the city, as the main sources had yet to be published, he nevertheless created a convincing imaginary view. To identify this as Batavia, he indicated a fort at center, while at right are stock buildings--narrow two-story homes with step gables. A row of trees is visible above the houses, perhaps indicating the tree-lined Tijgersgracht; nevertheless, this residential section is misplaced, as a more accurate view would indicate large warehouses in this quarter. This rendering of the city seems to have exaggerated the similarities of Batavia to home in order to secure it in the public imagination as Dutch.

25 The founders of the city of Batavia intended that it should look and feel Dutch as a means of establishing a dominant and cohesive Dutch population in a context of Dutch colonialism. For Dutch residents, surrounded by a tropical foreignness and trading with local Javanese, Chinese, and other European merchants in Batavia, the comforts of home were far away. Because the status of the Batavians as Dutch was constantly challenged by the diverse population and tropical environment, it was important to create a Dutch environment in the tropics that would recall the comfort of daily life at home in the Dutch Republic, thus reinforcing the residents' identification as Dutchmen. When returning from a trading voyage to Japan, a Dutch merchant could come home to Batavia, stroll Dutch streets along Dutch canals, populated by Dutch townhouses. This would go a long way toward mitigating any feelings of foreignness or alienation in his experience of the place, counteracting its settlement by a very mixed group of people, the warm humid air, and the exotic odors of the tropics.

\section{Dutch City Planning Principles in the Seventeenth Century}

26 The characteristics that were perceived as Dutch in Batavia, the canals and grid, fit into a larger model of seventeenth-century Dutch urban planning, both in the Dutch Republic and its overseas settlements. The city plan also reflects the theoretical models of the mathematician and engineer Simon Stevin. The seventeenth-century Dutch oversaw the building of new cities and the expansion of established cities throughout the world. Several scholars have discussed the qualities of Dutch urban planning in the period, but there is more to say about the importance of hierarchy in their examples. Batavia offers a prime case study for exploring the idea of control imposed by the 
built environment. Here was a newly built city, with a population we know to have been strictly divided and hierarchically structured, yet the urban fabric hid these inequalities through the misleading appearance of equal access and potential mobility throughout the city. The very real social stratifications were further exacerbated by ostentatious dress and behavior that underlined the city's inhabitants' concern with rank. I shall suggest that in Batavia the restrictions placed upon inappropriate displays of rank developed precisely because these displays exposed too conspicuously the inherently hierarchical nature of the city's environment and its population.

27 A remarkable consistency exists among Dutch seventeenth-century urban plans, both for cities in the Dutch Republic and for overseas settlements. Remaining evidence of these plans shows formal as well as ideological similarities, which suggest a shared Dutch ideology of the city, regardless of differences among individual planners and despite the absence of a centralized urban planning authority. In that regard, the Dutch situation contrasts with, for example, the Spanish Laws of the Indies, which stipulated a common framework for the arrangement and government of all Spanish colonial cities. ${ }^{39}$ Dutch colonial cities were subtly differentiated from the cities of the Dutch Republic: Dutch seventeenth-century urban planning generally made use of a rectilinear grid adapted to local circumstances and included canals or manipulated waterways and bastioned walls, but the overseas settlements made additional allowances for protection, with forts that had military, administrative, and trading functions. Remco Raben sees the form of Dutch colonial cities as indicative overall of a careful pragmatism, while Charles van den Heuvel focuses on the Dutch grid, noting its flexibility and adaptability to many landscapes. ${ }^{40}$ Ron van Oers asserts that Simon Stevin's "Ideal Plan for a City" was the organizing factor for Dutch colonial cities, with its underlying principles of spatial and societal order, protection, and water control. ${ }^{41}$ Each of these scholars notes in passing the hierarchies established by the city plans, but my reading emphasizes the hierarchical aspect of such plans, a hierarchy that subtly enforces a social order while disguising it under the appearance of a regular grid that seemingly promotes egalitarianism.

28 Several prominent examples demonstrate general Dutch urban planning principles in the seventeenth century: Simon Stevin's ideal plan, the development of the Dutch grid, and finally the expansion of Amsterdam. As a Dutch-planned city, Batavia demonstrates these principles and, as I will establish, it more fully manifests the hierarchy already inherent in Dutch seventeenth-century planning. As a new-built city, not subject to the constraints of previous infrastructure, Batavia reveals the hierarchical social divisions that were the goal of Dutch planning in the period.

29 Simon Stevin's “Ideal Plan for a City" looms large in discussions of Dutch urban planning in the seventeenth century, and particularly in the plan of Batavia, to which it bears some resemblance. Stevin's plan indicates his primary planning principles, which are also apparent in built Dutch cities, suggesting either that Stevin was a source for these plans, or that Stevin's plan itself reflected Dutch planning ideals more generally. Stevin described and illustrated his ideal plan in his Materiae Politicae (1650), in a chapter entitled "Distinguishing the Order of Cities" (Onderscheyt vande Oirdeningh der Steden). He set out what appears to be an evenly measured and balanced city (fig. 11). ${ }^{42}$ Stevin died in 1620 leaving several works that would be published posthumously in 1650, including the ideal plan and the beginnings of his work on house building. ${ }^{43}$ Stevin provided plans for the Dutch military up until his death, and he appears also to have advised the VOC on town planning in 1618, though there is no conclusive evidence that he actually plotted 
the VOC's cities. ${ }^{4}$

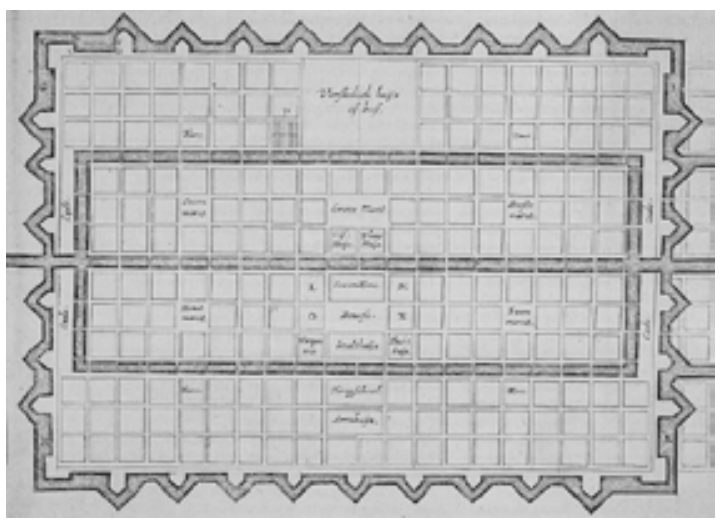

Fig. 11 Simon Stevin, Ideal Plan for a City, 1650. From Simon Stevin, Materiae Politicae: Burgherlicke Stoffen; vervanghende ghedachtenissen der oeffeninghen des doorluchtichsten Prince Maurits van Orangie (Leiden: Justus Livius, 1650) (artwork in the public domain)

30 Stevin's plan differs from other seventeenth-century ideal plans because of its rectangular shape, which is reminiscent of a Roman military camp (castrum), a type Stevin was familiar with from his military engineering work. ${ }^{45}$ Stevin preferred a rectangular city because the land within would be divisible into regular parcels, rather than the irregularly shaped blocks formed by rounded plans. ${ }^{46}$ Like the Roman castrum, Stevin's plan has an unimpeded wide street running through the center, which he, fitting the Dutch context, envisioned as a canal. Bisecting this is a series of open spaces and important buildings, an axis of public space. Stevin elaborated on the Roman square city plan, while emphasizing the Dutch elements of water control and spatial and societal order.

31 Water determines much of the form of Stevin's ideal city plan. A canal bisects this rectangular city horizontally and passes through the walls on either end. A secondary rectangular canal, which echoes the shape of the city, connects to the main canal at either end just inside the walls. ${ }^{47} \mathrm{~A}$ moat surrounds the city walls, which has a defensive function, strengthening the function of the wall as barrier between the city and the surrounding area. This extensive use of water is typical of many Dutch cities. The city is divided into four bands by the canals, and each of these is divided into square blocks of equal size, arranged in bands three deep. An axis perpendicular to the main canal divides the city in half vertically, and along this axis are spaces and buildings necessary to the function of the city: markets, city hall, the exchange, a church, and the royal palace. This vertical division of public buildings and the horizontal division of the main canal divide the city into four quadrants, each of which has its own specialized market in line with the main market or exchange, and its own church adjoining the canal. This subdivision suggests that the citizens could be organized into four groups with equal access to public buildings, or that it could be divided into equal-sized groups by religious affiliation. ${ }^{48}$

32 The standardized blocks throughout the city convey a sense of fair and democratic division of building parcels of equal value, but a further look reveals a hierarchy at work. The blocks along the canals are of higher value because of their easier access to transportation and to the pleasant views of the canals. The blocks closer to the central vertical axis have a privileged proximity to public buildings. The double band of blocks at top and bottom of the plan has no access to canals. That Stevin envisioned this location for laborer's residences shows he saw this as a less desirable zone. ${ }^{49}$ Van Oers points out that a hierarchy is clear in the positioning of the school (Hoogschool) on the canal, opposite the town hall (Stadthü̈s), in relation to the poorhouse (Armhü̈s), which is 
hidden from public view behind the school--the poorhouse is a less desirable public building and is thus isolated from the preferred public buildings. ${ }^{50}$ Similarly, the two buildings that flank the town hall are both punitive, the prison (Vangenis) and the workhouse (Tuchthü̈s). These are in a position semihidden from the open exchange square, yet are still centrally located and able to be surveilled from the town hall. ${ }^{51}$ As an ideal city, Stevin's plan expresses his goals for a Dutch city and thus for the people living in that city. His plan encourages residents to trade goods, defend themselves from outsiders, and, above all, develop a social hierarchy.

33 Central to my reading of Stevin's plan is the hierarchy encoded in its gridded design. A grid conceals hierarchy through its apparent egalitarianism; it retains the appearance of a uniform division of space that upon further examination proves otherwise. A careful examination of the placement of public buildings and the ease of access to transportation shows that certain positions on the grid are more desirable, a point made in Stevin's city and especially strongly in the case of Batavia. The following discussion of the grid, both in the Netherlands and in general, demonstrates the inherent hierarchies of this form, despite arguments that it is merely practical or rational or, indeed, egalitarian.

34 Charles van den Heuvel sees the seventeenth-century Dutch grid as deriving not from Stevin's plan but from indigenous systems of land parceling in the Low Countries. ${ }^{52}$ In city expansions and polder developments, land was generally divided on a gridded system. ${ }^{53}$ This, he argues, was the result of previous efforts to drain land through controlled waterways; these canals provided the beginnings of a rectilinear framework, on which a gridiron division of space was then overlaid. ${ }^{54}$ The Dutch grid, following Van den Heuvel, was a practical way of evenly parceling land on an existing canal framework, an argument that echoes Stevin's justification for a rectangular city, and Raben's hypothesis of Dutch pragmatism. These and related explanations exclude the inherent hierarchy of the grid.

35 Van den Heuvel notes a further source of the Dutch grid, which also derives from Stevin, but from a different text than the ideal plan. Stevin provided instructions for establishing military camps in his Castrametatio, published in $1617 .{ }^{55}$ Stevin suggested that a military camp should begin on paper with a rectangular outline, and then squares and rectangles representing the military quarters should be cut out and arranged on the outline until a satisfactory arrangement is determined. The way these elements were to be arranged demonstrates that this project was essentially hierarchical. The central position is assigned first, to the highest-ranking officers, and then the rest of the units are arranged around them. In this pragmatic grid, spatial proximity to the highest-ranking officers reflects one's position in the military hierarchy, a demonstration that this grid is important for its sensitivity to rank rather than its even parceling. The consistent use of gridded divisions in different types of Dutch planning indicates a general Dutch impulse to use the grid as a means for creating and dividing land, which perhaps cannot be traced to a specific source.

36 A final consideration is that a grid is more than simply a logical way to parcel land. Grid plans have been identified by some scholars with Dutch egalitarianism and pragmatism, as the Dutch preferred a simple grid to the baroque diagonals created in other European cities in the period. ${ }^{56}$ In contexts outside of the Dutch situation, the grid has been described as a means of ordering a 
population, an argument I find particularly cogent for understanding Batavia. Hannah B. Higgens has recently argued that the grid above all provides social organization: "It systematizes the relationship between the individual body and the acculturated spaces of our towns and cities, not in terms of the organic forms dictated by nature, but in terms of organized social systems." 57 Dell Upton, in his discussion of early American cities, argues that the grid was a way of spatially defining the social, political, and economic order, what he terms the "spatial imagination." ${ }^{2}$ His exploration of the grid in prison planning shows that the use of the grid to determine social relationships, even punitive ones, was an advantage noted by eighteenth- and nineteenth-century builders and theorists. ${ }^{59} \mathrm{~A}$ grid is a means of concealing unequal access to shared resources through ostensibly evenly ordered space, a format that always provides a matrix for hierarchical social order. Its use in urban planning means the city's form does the work of organizing the population, in the absence of, or with minimal, overt regulation of the populace. In a gridded city like Stevin's ideal one or in a place like Batavia, the social order, the organization and divisions of the population, is made explicit by the canals and parceling of land.

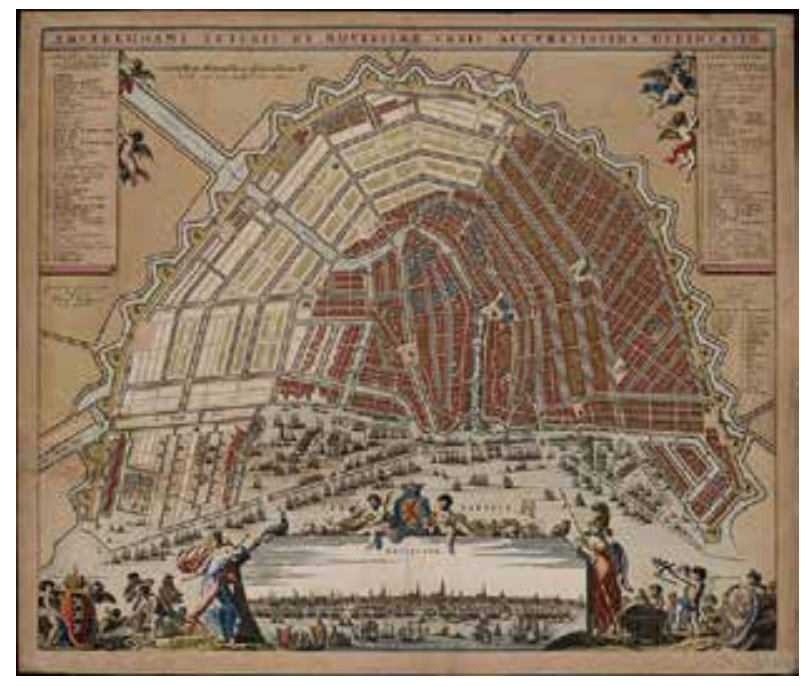

Fig. 12 Daniël Stalpaert, Map of Amsterdam, 1662 (printed by Nicolaes Visscher) (artwork in the public domain)

37 The hierarchies of Dutch city planning can be found in the Dutch Republic as well; it is not solely a concern of the colonial city, military encampments, or of Simon Stevin. The third expansion of Amsterdam, begun in 1613, demonstrates this. The expansion added to the west of the city the famous Ring Canals (from the center of the city outward: the Herengracht [Gentlemen's Canal], Keizersgracht [Emperor's Canal], and Prinsengracht [Prince's Canal]) and the more modest residential area, the Jordaan (fig. 12) ${ }^{60}$ The expansion was necessitated by the rapid growth of the city's population from the end of the sixteenth century through the seventeenth. The extension was physically shaped by the existing city, which it wrapped around. The Dutch planning principles outlined above can be seen to some degree in this section of the city: water control through canals and locks, gridded division of space, emphasis on the efficiency of transportation, and the distribution of public buildings. The clearest example of a subverted and particularly Dutch hierarchy is seen in the naming of the canals: the Herengracht was the most prestigious address, reflecting the high position of the nonaristocratic leaders of the city, a newly risen class in the Republic. Following this, the emperor and then the prince, out of the expected order, seem to 
reflect less concern for strict ranking.

38 However, all three canals were prestigious addresses, and the differences between them were negligible. A more compelling consideration is the relationship between the canal belt and the often-overlooked Jordaan, which made up the majority of the expansion. The Jordaan, now a quiet residential area, was historically the working-class quarter of the city. It is morphologically differentiated from the canal belt by the orientation of its grid, with streets and canals at a forty-five degree angle to those of the canal belt. This contrast is by circumstance rather than design; reflecting Van den Heuvel's argument of practicality, the orientation of the Jordaan's grid reflects the preexisting manipulated water system. The canal belt was created through an expensive reorientation of the existing water system to wrap around the city's core, and there were simply not enough resources available to expand this engineering project through the Jordaan. ${ }^{61}$ Additionally, before the planners were able to begin reorganizing the structure of the Jordaan, this area had given rise to a great deal of illegal infrastructure--houses had been built along the old footpaths in this angled orientation. By leaving the illegal buildings in place, the city of Amsterdam avoided the expensive project of reorganizing the urban infrastructure and also avoided the social and political conflicts that would result from destroying the illegal settlements.

39 A class division is built into the landscape of Amsterdam's third expansion by the uneven investment in the canal and road infrastructure. While it might be possible for this to be read as a support for seventeenth-century "squatter's rights," it was also a convenient argument for not spending already tight resources on the Jordaan. Amsterdam's third expansion demonstrates a reordered hierarchy through the naming of the prestigious canals, and it also embedded a continuing class hierarchy through the relationship of this smaller portion of the expansion to the Jordaan. The hierarchies apparent in these examples are essential for understanding Dutch seventeenth-century urban planning, especially as it extends to Batavia.

\section{Hierarchy in Batavia}

40 In his study of Dutch colonial cities, Ron van Oers asserts that Stevin's plan constituted the underlying organizational form for all these cities and that this is most clear for Batavia. There are certainly many formal connections, whether Stevin's plan was the source, or whether the principles his plan shares with other Dutch seventeenth-century urban planning lie at the root of Batavia's plan. Visual associations between these plans may have even contributed to the idea that Batavia manifested similar ideals. A consideration of the 1681 map (see fig. 4) alongside Stevin's plan (see fig. 11) demonstrates how Batavia's plan fostered still stronger divisions and a recognition of hierarchy in the citizenry of this city. Batavia resembles Stevin's plan in its rectangular proportions, its central canal that redirected the Ciliwung River, and the water outside of the bastioned wall that functions as an additional protective barrier. The rectilinear divisions of the city blocks by streets and secondary canals additionally recall Stevin's ideal city.

41 Yet despite many formal similarities between its plan and that of Stevin's ideal, Batavia was a far less egalitarian city. As the capital city of the VOC, Batavia represented the aspirations of the trading company and formed in many ways the face of the Dutch in the East. Founded two decades after the VOC began trading in the archipelago, Batavia was not built in haste, but rather carefully planned and plotted so that it could function as the eastern capital. Hierarchy was crucial to 
preserving the balance of power in the city, and the hierarchies present in Stevin's ideal are even more apparent in Batavia.

42 The differences between Batavia and Stevin's plan suggest that Batavia's form was not directly attributable to Stevin's ideas. They also underscore the stronger hierarchies present in this colonial city. Batavia introduced a much more rigid hierarchy through the inequitable access that the population had to the city. Walls that in Stevin's city are barriers to outside forces became in Batavia walls that formed barriers to the Chinese and enslaved populations who were resettled outside the walls. Canals that in Stevin's city provide transportation both on water and on foot via regular bridges became barriers in Batavia because Batavia had fewer bridges. Stevin made some provision for his four quadrants to differ in religious affiliation, yet maintain equal access to the public buildings of the city. Batavia's population and public spaces were distributed unevenly throughout the city, with varying levels of access and mobility.

43 As in Stevin's plan, a hierarchy of location is apparent upon further study of Batavia's plan. But Batavia was further reshaped by the varying widths of its streets and canals, providing the potential for greater volumes of traffic, enhanced accessibility, and improved visibility--in some places more than others. The north-south canal in the top half of Batavia, the Tijgersgracht, was the most fashionable address for prosperous Batavians. It was flanked by rows of trees (seen in fig. 10)--a feature not shared with every canal. The city's public buildings were not distributed centrally or evenly: most important buildings, like the churches and city hall, were built near the Tijgersgracht in the southeast quarter of the city, while warehouses were in the northwest quarter, closest to the harbor. Skilled workers labored along the eastern wall, and residential architecture was built throughout the city.

44 The bridges give further indication of the clear division of the city into isolated sections, in a hierarchy considerably starker than what Stevin's plan merely suggests, with his bands of blocks at varying distance from the canals and public axis of the city. The canals in both his ideal plan and the plan for Batavia provided a means of transportation, but in many sections of Batavia they were unbridged and thus became an obstacle to land transportation. A key difference between the plans is that Stevin's plan shows a bridge spanning the canals each time a street meets water, while Batavia's had far fewer bridges. The main canal is only bridged at one point on the 1681 map, effectively isolating the east and west halves of the city from one another. A second bridge, a small drawbridge that is still extant, had been built in 1655 near the northernmost canal of the east half of the city. For obvious reasons this bridge did not appear on the 1650 map on which the 1681 map was based, but it also is not indicated on the 1681 map--a clear sign that the later map is a close copy of the earlier version. As the main canal was the widest, having to accommodate larger boats, this lack of bridges is somewhat understandable. Nevertheless, this rendered the canal a major barrier to movement on foot or horseback or in a carriage. The location of smaller bridges shows that the city was effectively divided further into quarters--the fort was isolated in the eastern half, and the western half of the city was divided roughly in two by the Maleidschegracht, which was only bridged at its eastern and western edges. Within these quarters, the canals were more regularly bridged, so land transportation was less impeded. Residential architecture was present in all quarters, but Batavia's residents were not evenly distributed throughout the gridded city, so these disjunctures were barriers that separated populations within the city. 
45 The walls of the city constituted a further barrier to some segments of the Batavian population. Initially meant as protection from competing sea powers and indigenous armies, they evolved into protection from perceived internal threats. Two populations that were indispensible to the functioning of the city, the Chinese and the enslaved, were designated as potentially harmful and thus relocated outside of these walls. The population of Batavia was distributed throughout the city so that each ethnic group had its own district. The form of the city reinforced these divisions and kept groups divided by canals and walls, a major contrast with Stevin's city, which conferred equal access on all the citizens of the city, even if some had to travel farther to reach its important areas. Stevin's plan introduces a social hierarchy based on proximity to desirable locations, while the city of Batavia as built incorporated barriers to movement that contributed to the organization and control of the population.

46 These differences between Stevin's ideal plan and Batavia as it was ultimately constituted show that Stevin's plan was not the conclusive source for Batavia, but rather that both plans are consistent with Dutch seventeenth-century planning principles. As a newly built city, Batavia represented the ideals of Dutch seventeenth-century planning, when not constrained by the existence of previous infrastructure. As such, it more clearly manifested the rectilinear grid, the canals, and the restricted number of bridges crossing these (a problem one encounters in any canalled city). Yet it is important to note that the Dutch hierarchy is distinguished by its concealed nature: the social structure within the city was subtly structured by barriers to movement. These barriers were porous; one could reach any desired quarter of the city. Nevertheless, these barriers made certain routes and destinations less convenient, thereby shaping the way residents used the city.

47 What separates Dutch planning in the Republic from that in the colony is only the degree, not the presence, of hierarchy. In Batavia this hierarchy was exposed by the VOC administration's frustration, ultimately expressed in legislation, with the overt performance of rank displayed by the Batavian citizens. This un-Dutch ostentation calls for a closer look at the social hierarchies of this city and their cause. Considered through the lens of the colonial situation, hierarchy is anticipated, but a closer look at Batavia in the context of seventeenth-century Dutch planning ultimately reveals that colonial Batavia enacted the same principles as did planning in the Dutch Republic.

\section{Ordering Batavia's Population}

48 Batavia's built environment served on the one hand to promote a Dutch identity among the diverse Dutch residents of Batavia, allowing a more cohesive group to dominate over the nonDutch residents. On the other hand, Batavia dispersed the remaining population into distinct quarters that were separated by unbridged canals and barrier-forming walls. Anthony King argues in his study of colonial Delhi that division between populations is inherent to a colonial city, between a dominant and subordinate culture, the colonizer and colonized. ${ }^{62}$ The example of Batavia, where multiple cultures (Dutch, Eurasian, Chinese, enslaved, etc.) were in contact, is more complicated, and the city took this into account from its inception, hierarchically organizing the population through the arrangement of space. While Batavia shared with other colonial cities what King identifies as the feature of uneven contact, such hierarchies were also apparent in the Dutch metropole. An overt exercise of hierarchy and population control was rarely seen in Batavia or in the Dutch Republic, but a concealed hierarchy enforced by the built environment 
was intentional and very Dutch.

As I have suggested, a major role of Batavia's built environment was to strengthen the Dutch identity of this dominant group in the colonial city. The trade networks of the archipelago had functioned to establish a strikingly diverse population in the trading ports of the region. ${ }^{63}$ Before the arrival of European traders, indigenous residents had worked alongside Chinese and Middle Eastern merchants. In the ports they were joined by Portuguese, Dutch, and English merchants, to name but a few of the groups present in the area when Batavia was established. After the Dutch gained control of the area, defeating the local rulers and the English, the population remained diverse, though Javanese were for the most part excluded from trading. Javanese and other islanders, Chinese, Indian, and non-Dutch Europeans, made up the vast majority of the population of Batavia. A 1673 survey showed some 27,000 people living within the city walls, of which approximately 2,000 were Dutch, 700 were Eurasian, 2,800 were Chinese, 5,000 were of Indian descent, 3,000 were from Java and the rest of the archipelago, and 13,000 were slaves of unnamed origin. ${ }^{64}$

50 Among the ten percent of the population that was considered Dutch in this survey there remained a great deal of diversity of origin and social status. ${ }^{65}$ This Dutch population was mostly made up of employees of the company and their dependents. ${ }^{66}$ The legal classification of "Dutch" included those who had been born in the Dutch Republic and relocated to the Indies, children born of Dutch parents in Batavia (creoles), wives of Dutchmen (but not concubines), and children of Dutchmen regardless of maternal lineage; the Dutch group expanded exponentially as offspring from all of these groups continued to be considered Dutch. ${ }^{67}$ Ann Laura Stoler points out that this broad definition of Dutch, including what would amount to a substantial Indisch population, served to keep this group allied with European colonial interests. ${ }^{68}$ Jean Gelman Taylor shows that the Europeans in the Dutch group were insulated by the inclusion of Eurasians and creoles in their group from the other major ethnicities of Batavia. ${ }^{69}$

51 No non-Dutch Europeans are included as residents according to this survey, which does not reflect the actual situation--these were likely folded into the Dutch group. Looking at the nationalities of a group of VOC soldiers gives us some insight into the ethnic make-up of this ten-percent Dutch population. In 1622, of 143 soldiers in Batavia, only 57 were Dutch, while the remaining sixty percent were German, Swiss, English, Scottish, Danish, Flemish, Walloon, and of unknown nationality. ${ }^{70}$

52 The Dutch group additionally included people considered undesirable or degenerate. Sailors and soldiers, who had a very low status in Dutch accounts of the period, made up a large portion of this group. ${ }^{71}$ Regarding the permanent citizens of Batavia, an early complaint came from the first governor-general of Batavia, Coen, who famously wrote to Amsterdam lamenting that only the "scum of the earth" were settling the city. ${ }^{72}$ The cross section of Dutch society that became the ruling elite of Batavia perhaps offers an additional clue as to why Dutch Batavians dressed and acted out of rank and ultimately required sumptuary laws: unaccustomed to wealth and power, many Batavian Dutch had no experience of the accepted Dutch expressions of rank. ${ }^{73}$ The attention to rank and debates over the trappings of prestige within the Dutch group eroded this group's coherence. The apparent laxity in what constituted Dutch ethnicity--one did not need to speak Dutch, need never have resided in or visited the Netherlands, in fact required no distinct ties to 
the Republic--contrasts with the divisions enforced upon the Asian and enslaved populations. An environment that could form this diverse Dutch population into a group with a collective Dutch identity served the VOC's need to ensure that their capital appeared to be Dutch, and that the Dutch residents could dominate the other ninety percent of the population.

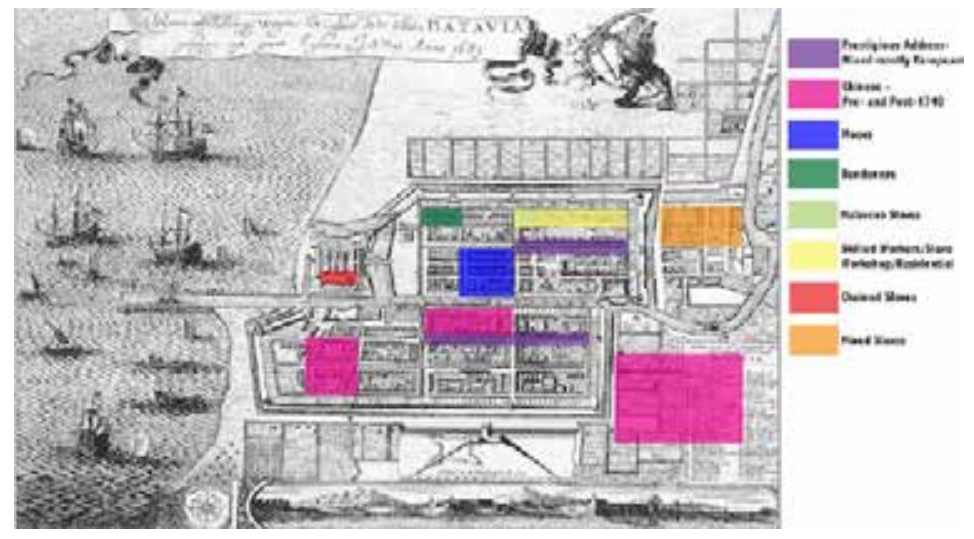

Fig. 13 Distribution of Population in Batavia (Source: author's alteration of Figure 4.)

53 The location of the various ethnic groups of Batavia in the city shows the role of the built environment in maintaining divisions between the non-Dutch residents of the city. Some of these populations' locations are noted in Figure 13. The key of the 1681 map indicates the location of two of the city's groups, the Bandanese in the northeast corner of the city, and the Mallaccan slaves (here labeled Mallabaer) in the northernmost quarter of the workshop area (see fig. 4$).{ }^{74}$ On the 1780 map, the Chinese neighborhood, outside the walls directly south of the west half of the city, is labeled clearly as "Chine Kwartier" (see fig. 7). Further designations can be found through a close reading of Frederik de Haan's two-volume Oud Batavia. De Haan describes historic Batavia in minute detail in this work published in celebration of the three-hundred-year anniversary of the founding of Batavia. His passing mention of certain zones as the location of different ethnic groups is both a reflection of his historical research and the accretion of years of place memory in Batavia--ethnic divisions unseen to present researchers in decolonized Jakarta. Within chapters describing the founding of the city, the streets and walls, the different ethnic groups, and even the furniture of Batavia, De Haan inadvertently also describes the separation of the people of the city into distinct quarters.

54 The most wealthy residents, mainly European-derived merchants and officials and Chinese merchants, lived along the Tijgersgracht in the southeast quarter of the city, or in the second-most prestigious location, the Jonckersgracht (approximately translated as Squire's Canal) in the southwest quarter. ${ }^{75}$ The Chinese of Jonckersgracht lived north of Utrechtstraat and the Europeans south of it. ${ }^{76}$ Free workers of all origins lived in the northwest corner of the city, near the warehouses. ${ }^{77}$ Slave craftsmen worked in the Ambachtskwartier ([Craft] Working Quarter), at the southeast corner adjacent to the wall. ${ }^{78}$ Incidentally, this is the same section that in Stevin's ideal plan was the laborers' area. Moors lived and worked to the north of the Leeuwinnengracht. ${ }^{79}$ Before the Chinese Massacre of 1740, the Chinese lived throughout the city, but they were concentrated in the center of the west half of the city, and they situated their own warehouses near those of the VOC.$^{80}$ Chained slaves lived in the fort, while skilled and unskilled slaves lived either where they worked, or in a slave quarter outside the wall to the south of the Ambachtskwartier. ${ }^{81}$ 
55 Some of these groups, like the slaves and the Chinese post-1740, were compelled to live in specific neighborhoods by law, while other groups' locations were determined by their occupation. Wealthy residents chose open tree-lined canals. A group's relative access, controlled by bridges and the city wall, affected its mobility and separated it into a distinct entity. Yet, for residents within the walls, the barriers and divisions were porous. Any part of the city could be reached, but the relative difficulty of a route subtly shaped mobility, concealing the city's hierarchy through the pretense of freedom of movement.

56 Beginning in the mid-eighteenth century, as the canals silted up and grew stinky and diseased, the wealthy Europeans moved north of the city environs, building villas rather than townhouses. The historic city core became a place for low-income residents who could not afford the healthier countryside. The result was a further separation within the social hierarchy of Batavia.

57 Changes in the city between its initial completion and the late eighteenth century are apparent by comparing the maps of 1681 and 1780, representing two thorough land surveys (see figs. 4 and 7). The enslaved and Chinese populations were consolidated outside of the city walls, to the south, in sections isolated by canals and very few bridges, and separated from the city center by the wall. By 1780 , the central canal of Batavia was bridged more regularly, perhaps because the most threatening populations had been moved outside the walls. This allowed mobility within the city to become slightly freer. An interesting change, relevant to the sumptuary laws, is the expansion of the parade ground between the city and the fort, and the plaza in front of the town hall (Stadhuis, built 1707-10) in the southeast quarter. City ordinances of 1719 and 1754 regulating modes of transportation and procession underscore the importance of parading through space as a way for Batavians to express themselves, regardless of whether it was appropriate to their rank. ${ }^{82}$

As we have seen, the dominant group in Batavia seldom blatantly demonstrated their position above the other population groups, preferring to let the built environment more subtly shape the hierarchy. The Chinese Massacre of 1740 was a crucial exception. The Chinese were an important and integral part of the city's functioning, serving as merchants with ties to China and the all-important porcelain trade, as well as shopkeepers, laborers, and sugar farmers and processors. Some Chinese merchants rose to high positions, living among the European wealthy on the fashionable canals. In 1733, select Chinese citizens were accorded the right to walk with a parasol-bearing servant, suggesting that class distinctions similar to those among the Dutch Batavians had developed. ${ }^{83}$ The Chinese Massacre collapsed this group into a homogenously feared entity and reoriented their relationship to the urban plan. ${ }^{84}$ The Chinese Massacre signified the hysterical reaction of the Dutch Batavians to their fear of revolt among Chinese workers located outside the city. More than a thousand Chinese living within the city walls were slaughtered; and a Chinese quarter was subsequently established outside the walls south of the city to protect the city's population from any suggestion of rebellion or retaliation. ${ }^{85}$ Before the massacre the Chinese had lived in many parts of the city according to their respective economic status and occupation. But after 1740 , they were forced into a homogenized ethnic neighborhood, separated from the rest of the city by a wall and canal.

59 Slaves occupied the lowest level of Batavia's hierarchy. This group, which made up nearly half 
the city's population, was highly diverse in ethnicity, status, and occupation. ${ }^{86}$ Until 1664 , the work done by the slaves determined their location in the city. ${ }^{87}$ Four main types of slave lived in seventeenth-century Batavia: the household slave, the chained slave, the craftsman, and the kuli. The household slaves generally lived behind the house of the master. ${ }^{88}$ The chained slaves (kettinggangers) were people from many ethnic groups and social levels, including Europeans, enslaved as a punitive measure. Housed in the fort, they were kept in chains and did heavy manual labor, much of it dangerous, like the digging and dredging of canals. ${ }^{89}$ The skilled laborers, who were a respected group owned by the VOC, initially lived in the section of the city where they worked, the Ambachtskwartier. Kulis (unskilled laborers owned by citizens of Batavia) lived in the slave quarter south of the city walls, where they were later joined by the skilled laborers. In 1664, the chained slaves were also moved to the slave quarter, when this became a quarter for all types of slaves, and the divisions among their laboring status became blurred. ${ }^{90}$ This led to a clearer division between the slave and nonslave population, while still keeping the skilled slaves near enough to the quarter where they worked. This also ensured that a fortified wall stood between the slaves and the fashionable Tijgersgracht.

In marked contrast to the imagined Dutch merchant mentioned earlier, whose sensation of the foreignness of the East Indies was mitigated by Batavia's many references to his Dutch homeland, a skilled slave heading to his workshop on the 1681 map had a very different experience of the city. After heading north from the slave quarter, he would have crossed a drawbridge and passed through the Nieuwe Poort (New Gate) (see fig. 4). Crossing a bridge over a canal, he would then have headed east toward the workshops, staying off the sidewalks that were forbidden to him, which further shaped his experience of the city plan. ${ }^{91}$ His view as he walked was either of the fashionable Tijgersgracht on his left, by this time of day busy with the activity of household slaves, or on his right the parklike band just inside the walls, planted with trees and perfect for strolling, but not connected by footbridge to his workplace--so an impractical route. He would have retraced this path at the end of the workday, when the gate and drawbridge were closed behind him, protecting the city residents from any threat of slave revolt. Rather than evoking feelings of connections to the Dutch Republic, the canals for this slave would have been a barrier to movement, directing his path to and from work and residence. ${ }^{92}$ These different relationships to the urban morphology of Batavia reinforced the divisions between the slave and free populations of Batavia, and among the types of slaves, keeping them divided by canals, the city walls, the sidewalk, and even the house versus the rear yard, in the case of household slaves.

61 Social divisions between ethnic groups contributed to the sense of separation of both free and enslaved groups. The VOC promoted ethnic divisions among slaves to secure the city against slave uprisings. Despite their shared living area after 1664, the slaves remained divided by origin, religion, and status. Ethnic divisions were maintained among the slaves in large part because of European perceptions of the specific skills of each group and the relative risks presented by a particular group..$^{93}$ By treaty, no Javanese were slaves, as they were assumed to have the greatest motivation and means to escape their owners. Certain groups were prohibited because of a perception that they were dangerous: male slaves from Bali were avoided because of their tendency to run amok. The VOC also issued ordinances about who might own a slave and which religion that slave might practice. Not surprisingly, those ordinances served to maintain a hierarchy among slave owners, with Dutch Christians at the top. ${ }^{94}$ Outside of the very inclusive Dutch group, similar 
social divisions could be found in the free population of the city, a group which operated under a kampung organization. This was a locally derived practice, in which each ethnic group controlled its own neighborhood, led by an officer chosen from among the population. While empowering a group to partially self-govern, in effect this kept people from interacting or transferring among groups, by maintaining linguistic and ethnic divisions between populations.

\section{Conclusion}

62 The market scene in Beeckman's Castle of Batavia (see fig. 1) shows a microcosm of the VOC's trading network, as the city's diverse population mingles, some buying and selling produce or fish, others playing or talking. The segregation of this population, fostered by the division of the city by unbridged canals and walls, is for the most part obscured by this lively gathering. The slave leaning back under the weight of the parasol marks one couple as being of higher status, thereby exposing the essence of Batavia's hierarchy. The Dutch Batavians' attempted maintenance of a cohesive Dutch identity, enforced by reminders of the Dutch Republic in Batavia's built environment, was undermined by ostentatious displays of status by wealthier members of this society. The attempt by this group to demonstrate their dominance over others led to assertions of superiority within the allegedly cohesive Dutch group. Some manifestations of this hierarchy, such as the parasol, appear to have been adopted from the local population. However, only some specifics of this behavior can be attributed to local customs, for the preoccupation with hierarchy was utterly Dutch. At home, too, wealthy merchants expressed their higher social position by wearing costly dress, albeit in sober and unadorned black, ostensibly to demonstrate their lack of concern with that status. Indeed, Dutch urban planning practices of the seventeenth century, both overseas and in the Republic, demonstrate Dutch society's concern with hierarchy. Batavia presents a vivid illustration of how a city's very form served to expose the hierarchies inherent in all Dutch cities of the early modern period.

\section{Acknowledgments}

I would like to thank Anna Andrzejewski, Jill Casid, Jane Hutchison, Preeti Chopra, Jolanda Vanderwal Taylor, and Arijit Sen, who advised me on this topic in its beginnings as a dissertation chapter. I would additionally like to thank the editor and anonymous reviewers at JHNA, as well as Julie Hochstrasser, whose comments were indispensible in shaping the final form of this article. Melissa Mednicov and Mike Lorr also provided invaluable advice on this manuscript.

Marsely Kehoe is currently Mellon Post-Doctoral Fellow in the Department of Art History and Archeology at Columbia University. She has published on nautilus cups in Dutch Crossing, has presented on Batavia and Willemstad (Curaçao) at the conferences of the Vernacular Architecture Forum and Historians of Netherlandish Art, and will speak at the College Art Association conference and the Bruce Museum in 2015. She is preparing a manuscript on the global legacy of the Dutch golden age. marselykehoe@gmail.com

\section{List of Illustrations}

Fig. 1 Andries Beeckman, The Castle of Batavia, 1661, oil on canvas, 108 x $151.5 \mathrm{~cm}$. Rijksmuseum, Amsterdam, inv. no. SK-A-19 (Photo: Rijksmuseum, Amsterdam) (artwork in the public 
domain)

Fig. 2 Aelbert Cuyp, The Commander of the Homeward-Bound Fleet, ca. 1640-60, oil on canvas, 138 x 208 cm. Amsterdam, Rijksmuseum, inv. no. SK-A-2350 (Photo: Rijksmuseum, Amsterdam) (artwork in the public domain)

Fig. 3 Jacob Coeman, The Batavian Senior Merchant Pieter Cnoll, His Eurasian Wife and Daughters and Domestic Slaves, 1665, oil on canvas, 130 x $190.5 \mathrm{~cm}$. Amsterdam, Rijksmuseum, inv. no. SKA-4062 (Photo: Rijksmuseum, Amsterdam) (artwork in the public domain)

Fig. 4 Waere affbeeldinge Wegens het Casteel ende Stadt Batavia, 1681. Nationaal Archief, The Hague, VELH 430 (artwork in the public domain)

Fig. 5 Plan van 't fort en omleggende land Jacatra, 1619. Nationaal Archief, The Hague, Kaartcollectie Buitenland Leupe, 4.VEL 1176 (artwork in the public domain)

Fig. 6 Jacob Cornelisz Cuyck, Plan of Batavia, 1629 (copy by Hessel Gerritsz, 1630). Nationaal Archief, The Hague, Kaartcollectie Buitenland Leupe, 4.VEL 1179B (artwork in the public domain)

Figure 7. Plan der Stad en 't Kasteel Batavia (made under the direction of P. A. van der Parra in 1770, printed in Amsterdam by Petrus Conradi in 1780). Leiden University Library (KITLV Digital Image Library, image code D E 21,9@i) (artwork in the public domain)

Fig. 8 Carte de l'isle de Iava ou sont les villes de Batauia et Bantam, (detail), ca. 1720, watercolor. Newberry Library, Chicago, VAULT drawer Ayer MS map 30 sheet 47 (NLO) (Photo: courtesy of Newberry Library) (artwork in the public domain)

Fig. 9 Seventeenth-century houses in Batavia, ca. 1920, photograph. Leiden University Library (KITLV Digital Image Library, image code 88693) (artwork in the public domain)

Fig. 10 Johannes Nieuhof, Tijgersgracht (detail), 1682. From Johannes Nieuhof, Gedenkwaardige Brasiliaense zee- en landreis (Amsterdam: Widow of van Jacob van Meurs, 1682). Columbia University Libraries (Photo by author) (artwork in the public domain)

Fig. 11 Simon Stevin, Ideal Plan for a City, 1650. From Simon Stevin, Materiae Politicae: Bvrgherlicke Stoffen; vervanghende ghedachtenissen der oeffeninghen des doorluchtichsten Prince Maurits van Orangie (Leiden: Justus Livius, 1650) (artwork in the public domain)

Fig. 12 Daniël Stalpaert, Map of Amsterdam, 1662 (printed by Nicolaes Visscher) (artwork in the public domain)

Fig. 13 Distribution of Population in Batavia (Source: author's alteration of Figure 4.) 
${ }^{1}$ Jacobus Anne van der Chijs, Nederlandsch-Indisch Plakaatboek (Batavia: Landsdrukkerij, 18851900), 2:111. This law was inspired by complaints by the Dutch government about VOC employees using the parasol regardless of their station or need for shade ("Vooral in het gebruik van 'kieppesollen' [zonneschermen] was groot misbruik ingeslopen. Een iegelijk 'indifferent sonder aensien van qualiteyt ofte conditie', liet zich die door slaven boven het hoofd houden, 'meerder tot pompeusheyt, als uyt eenige nootwendicheyt."') and concludes that if one needs the parasol for shade or because of rain, then he must carry the parasol in his own hand. ("Waneer men eene zonnescherm gebruiken wilde 'tot schutsel van de son ofte voor de regen ofte om andere redenen,' dan moest men die 'selffs in de hand houden ende draegen."') In 1733, the right to use a parasol carried by a servant was extended more widely, but the fine was doubled for violating this ordinance (4:333-36). The sumptuary codes were established by decree of the governor general, in many cases in response to complaints from the Heeren XVII (advisory board, headquartered in the Republic) of the Dutch East India Company; they have been compiled, along with all other decrees of the governor and his council, in multiple volumes of the Plakaatboek.

${ }^{2}$ Subsequent regulations also governed one's movement through the city: a law of 1704 regulated the types of carriages and coaches in which Batavians could travel, and this was reiterated in 1729. Van der Chijs, Plakaatboek, 3:536-38; 4:236.

${ }^{3}$ It should be noted that sumptuary laws were rarely imposed in the Dutch Republic. See Simon Schama, The Embarrassment of Riches: An Interpretation of Dutch Culture in the Golden Age (New York: Vintage, 1987), 182, 186-87, and 634n113.

${ }^{4}$ Kees Zandvliet discusses the identification of the figures, and possible alternatives. Kees Zandvliet, ed., The Dutch Encounter with Asia: 1600-1950 (Zwolle: Waanders and Rijksmuseum Amsterdam, 2002), 182.

${ }^{5}$ All the figures have been identified, even the servants, see Zandvliet, Dutch Encounter, 200-202.

${ }^{6}$ Van der Chijs, Plakaatboek, 3:47-48. The code is vague enough to seem to forbid jewels to anyone but the family of the governor general and his council: "Alleen de vrouwen, kinderen en weduwen van den Gouverneur-Generaal en Raden van Indië mogten juweelen, enz. dragen." 7 The regulation was entitled: "Maatregelen ter beteugeling van pracht en praal." Van der Chijs, Plakaatboek, 6:773-95. Some violations that might be identified in portraiture include that a woman's social rank determined what size and value of pearls she was allowed to wear (an expansion of the 1680 regulations) and which men might wear what type of gold or silver border or fasteners on their coats (6:784-86).

${ }^{8}$ Jean Gelman Taylor, The Social World of Batavia: European and Eurasian in Dutch Asia (Madison: University of Wisconsin Press, 1983), 66. The sumptuary laws were revoked in 1795 with the dissolution of the VOC, in order to abolish demonstrations of rank (Van der Chijs, Plakaatboek, 12:137-42). On these laws, see also Susan Abeyasekere, Jakarta: A History, 2nd ed. (Singapore/ Oxford/New York: Oxford University Press, 1989), 36-38.

${ }^{9}$ On the Chinese source of the parasol, and the Chinese in Batavia more generally, see Dawn Odell, "Public Identity and Material Culture in Dutch Batavia," in Crossing Cultures: Conflict, Migration, and Convergence; The Proceedings of the 32nd International Congress on the History of Art, The University of Melbourne, 13-18 January 2008, ed. Jaynie Anderson (Carlton, Australia: Miegunyah Press, 2009), 253-57. See also the work of Leonard Blussé on the Chinese of Batavia. On Indonesian social behaviors of dominance, see Webb Keane, Signs of Recognition: Powers and Hazards of Representation in an Indonesian Society (Berkeley: University of California Press, 1997). 
${ }^{10}$ See Homi K. Bhabha, “The Other Question: Difference, Discrimination and the Discourse of Colonialism," in Out There: Marginalization and Contemporary Cultures, ed. Russell Ferguson et al. (Cambridge, Mass.: MIT Press, 1990), 71-87.

${ }^{11}$ On how the rhetoric of the colonial powers furthered this reputation, see Benjamin Schmidt, Innocence Abroad: The Dutch Imagination and the New World, 1570-1670 (Cambridge: Cambridge University Press, 2001), and Margaret R. Greer, Walter D. Mignolo, and Maureen Quilligan, eds., Rereading the Black Legend: The Discourses of Religious and Racial Difference in the Renaissance Empires (Chicago: University of Chicago Press, 2007).

${ }^{12}$ Swati Chattopadhyay, Representing Calcutta: Modernity, Nationalism, and the Colonial Uncanny (London: Routledge, 2005); and Brenda S. A. Yeoh, Contesting Space: Power Relations and the Urban Built Environment in Colonial Singapore (Kuala Lumpur: Oxford University Press, 1996). ${ }^{13}$ The authority on the early Dutch Republic is Jonathan Israel, The Dutch Republic: Its Rise, Greatness, and Fall 1477-1806 (Oxford: Clarendon Press, 1995); for an introduction to Dutch as traders, see C. R. Boxer, The Dutch Seaborne Empire 1600-1800 (New York: Penguin Books, 1965). ${ }^{14}$ On the Spice Island trade, see Anthony Reid, Southeast Asia in the Age of Commerce 1450-1680, 2 vols. (New Haven: Yale University Press, 1988/1993); and M. A. P. Meilink-Roelofsz, Asian Trade and European Influence in the Indonesian Archipelago between 1500 and about 1630 (The Hague: Martinus Nijhoff, 1962). For a reorientation of the Western account of this trade, see Robert Markley, The Far East and the English Imagination, 1600-1730 (Cambridge: Cambridge University Press, 2006), which despite the title, includes other European powers, especially the Dutch.

${ }^{15}$ A. van der Moer, Een zestiende-eeuwse Hollander in het Verre Oosten en het Hoge Noorden: Leven, werken, reizen en avonturen van Jan Huyghen van Linschoten (1563-1611) (The Hague: Martinus Nijhoff, 1979); and Els M. Jacobs, In Pursuit of Pepper and Tea: The Story of the Dutch East India Company (Zutphen: Walberg Pers, 1991), 7-12; and on Houtman, see Julie Berger Hochstrasser, Still Life and Trade in the Dutch Golden Age (New Haven: Yale University Press, 2007), 101-2, and 330n28.

${ }^{16}$ Hochstrasser, Still Life, 106; she also describes other atrocities committed by the Dutch.

${ }^{17}$ The foremost source on the history of Jakarta is Abeyasekere, Jakarta. This reference, 4-5.

${ }^{18}$ The oddly fortuitous series of events is detailed in Abeyasekere, Jakarta, 11-12.

${ }^{19}$ Israel, The Dutch Republic, 323.

${ }^{20}$ This began in the early sixteenth century when Tacitus's Germania was rediscovered. Joep Leerssen, National Thought in Europe: A Cultural History (Amsterdam: Amsterdam University Press, 2006), 39ff.

${ }^{21}$ It is interesting to note that the sumptuary laws became necessary after the city and the VOC began their slow decline.

${ }^{22}$ Jan de Vries and Ad van der Woude specifically identify 1663 as the turning point after which profits slow: Jan de Vries and Ad van der Woude, The First Modern Economy: Success, Failure, and Perseverance of the Dutch Economy, 1500-1815 (Cambridge: Cambridge University Press, 1997), 675ff; Els M. Jacobs shows that the VOC was too inflexible to accommodate these changes in supply and demand. Els M. Jacobs, Koopman in Azië: De Handel van de Verenigde Oost-Indische Compagnie tijdens de 18e Eeuw (Zutphen: Walberg Pers, 2000).

${ }^{23}$ Because of new saltwater ponds established along the shore of Batavia, a strain of malaria began affecting new arrivals in the city; the mortality of VOC employees increased from six percent within the first year of arrival to fifty percent beginning in 1733. This incredible strain on the 
employees of the VOC meant that the company dramatically increased the number of employees they recruited and sent to the East. This cost the VOC terribly and destroyed the profitability of the company in the eighteenth century. Peter H. van der Brug, "Unhealthy Batavia and the Decline of the VOC in the Eighteenth Century," in Jakarta/Batavia: Socio-Cultural Essays, ed. Kees Grijns and Peter J. M. Nas (Leiden: KITLV Press, 2000), 43-74.

${ }^{24}$ Elizabeth Sutton has explored this issue in the case of Dutch colonial Brazil: Elizabeth Sutton, "Possessing Brazil in Print, 1630-1654," Journal of Historians of Netherlandish Art 5, no. 1 (2013); www.jhna.org/. Accessed September 2, 2013.

${ }^{25}$ Linda Rupert suggests that the mapmakers of Willemstad, Curaçao, depicted the lower-class, and primarily African-derived, neighborhood of Otrobanda as undeveloped and disproportionately small to similarly dismiss this population in the capital of the Dutch West Indies. Linda M. Rupert, Creolization and Contraband: Curaçao in the Early Modern Atlantic World (Athens: University of Georgia Press, 2012), 128-31.

${ }^{26}$ A comparison to the contemporary Dutch colonial city of New Amsterdam (New York) shows a distinct difference in levels of planning: New Amsterdam developed organically, not following a grid, while Batavia was planned from its inception. This difference distinguished between the relative importance of these cities: Batavia was the VOC's eastern capital, while New Amsterdam was a small and unstable outpost. Manhattan's grid is not an extension of New Amsterdam, but a plan imposed in 1807; see Hannah B. Higgins, The Grid Book (Cambridge, Mass.: MIT Press, 2009), 69.

${ }^{27}$ Abeyasekere, Jakarta, 15. See also Leonard Blussé, "An Insane Administration and an Unsanitary Town: The Dutch East India Company and Batavia (1619-1799)," in Colonial Cities, ed. Robert J. Ross and Gerard J. Telkamp (Dordrecht: Martinus Nijhoff, 1985), 65-86; these authors discuss earlier documents about the city, such as Stamford Raffles's description from 1817. ${ }^{28}$ The map illustrated here was published in 1682, after being redrafted in 1681 by copying the 1650 version. Both the 1650 and 1681 versions exist in multiple copies, published throughout the following centuries.

${ }^{29}$ This map was produced directly after the establishment of the 1680 sumptuary laws outlawing the wearing of jewels or golden costume refinements for all but the highest-ranking VOC officials. ${ }^{30}$ With the dissolution of the VOC, and the Napoleonic Wars, Batavia's footprint changed: it was Herman Willem Daendels, a governor-general appointed by Napoleon's brother Louis, who destroyed the fort and the city walls, and built a new fort outside the city. In 1811, Batavia was lost to England and was ruled until 1816 by British Lieutenant-Governor Thomas Stamford Bingley Raffles, the founder of Singapore. He oversaw the building of a large English-style green south of Batavia, which shaped the suburb, Weltevreden, that grew up around it, resulting in the city having a different urban footprint than Dutch Batavia. Returned to Dutch hands under the terms of the Anglo-Dutch Treaty of 1814, the city retains its basic original shape, the rectangular city can still be seen in Jakarta's historic district today, minus the walls, and with most canals filled in and converted to roads.

${ }^{31}$ Spiro Kostof, The City Shaped: Urban Patterns and Meanings Through History (London: Thames and Hudson, 1991), 190, points out the usefulness of clear connections between the bastions and the roads or supply routes.

${ }^{32}$ François Valentijn, Oud en nieuw Oost-Indiën (Amsterdam: Johannes van Braam and Gerard Onder de Linden, 1724-26), 4:231.

${ }^{33}$ Valentijn, Oud en nieuw Oost-Indiën, 4:232; Johannes Nieuhof, Gedenkwaardige Brasiliaense 
zee- en landreis (Amsterdam: Widow of van Jacob van Meurs, 1682), 199.

${ }^{34}$ On Dutch buildings in Batavia and across their global empire, see C. L. Temminck Groll, ed., The Dutch Overseas: Architectural Survey: Mutual Heritage of Four Centuries in Three Continents (Zwolle: Waanders, 2002).

${ }^{35}$ The concept of architectural diffusion is explained in Fred Kniffen, "Folk Housing: Key to Diffusion," in Common Places: Readings in American Vernacular Architecture, ed. Dell Upton and John Michael Vlach (Athens: University of Georgia Press, 1986), 3-26.

${ }^{36}$ Temminck Groll asserts that these forms must derive locally. Temminck Groll, Dutch Overseas, 137.

${ }^{37}$ I have argued elsewhere that some of the Dutch-style buildings in the background of city views in this volume were added by the Amsterdam-based engravers of the drawings provided by Nieuhof, as a kind of architectural staffage that stands in for Dutch building types.

${ }^{38}$ Temminck Groll, Dutch Overseas, 70.

39 The Spanish Laws of the Indies, issued by the crown, purportedly set out a city plan to be imposed on Spanish colonies, though a closer look at the original text shows that this document is mostly concerned with the site and government of these cities, and calls for a grid city with a central plaza, but further details are lacking (for instance, no plan is provided). Like Dutch colonial cities, Spanish colonial cities were usually built on a rectangular grid, but they did not incorporate waterways and were less concerned with enabling trade through careful connections to the harbor. The Spanish colonies were more overtly concerned with maintaining royal and religious authority through a top-down implementation of urban planning. On the Laws of the Indies, see Valerie Fraser, The Architecture of Conquest: Building in the Viceroyalty of Peru 1535-1635 (Cambridge: Cambridge University Press, 1990); and Dora P. Crouch, Daniel J. Garr, and Axel I. Mundigo, Spanish City Planning in North America (Cambridge: MIT Press, 1982).

${ }^{40}$ Remco Raben, "Klein Holland in Azie: Ideologie en pragmatisme in de Nederlandse koloniale stedebouw, 1600-1800," Leidschrift 9, no. 2 (1993): 44-63; and Charles van den Heuvel, "Multilayered Grids and Dutch Town Planning: Flexibility and Temporality in the Design of Settlements in the Low Countries and Overseas," in Early Modern Urbanism and the Grid: Town Planning in the Low Countries in International Context; Exchanges in Theory and Practice 1550-1800, ed. P. Lombaerde and C. van den Heuvel (Turnhout: Brepols, 2011), 27-44.

${ }^{41}$ Ron van Oers, Dutch Town Planning Overseas During VOC and WIC Rule (1600-1800) (Zutphen, Walberg Pers, 2000), 10-11.

${ }^{42}$ Simon Stevin, Materiae Politicae. Bvrgherlicke Stoffen: vervanghende ghedachtenissen der oeffeninghen des doorluchtichsten Prince Maurits van Orangie (Leiden: Justus Livius, 1650), chapter 1: "Distinguishing the Order of Cities" ("Onderscheyt vande Oirdeningh der Steden"). I consulted the copy held in the Newberry Library, Chicago.

${ }^{43}$ E. J. Dijksterhuis, Simon Stevin: Science in the Netherlands around 1600 (The Hague: Martinus Nijhoff, 1970) is the most comprehensive source on the life and works of Stevin; see also the compilation and translation of his major works: Simon Stevin, Principal Works, ed. Ernst Crone and trans. C. Dikshoorn (Amsterdam: C. V. Swets \& Zeitlinger, 1955-66); and Charles van den Heuvel, "De Huysbou": A Reconstruction of an Unfinished Treatise on Architecture, Town Planning and Civil Engineering by Simon Stevin, trans. D. Gardner (Amsterdam: Koninklijke Nederlandse Akademie van Wetenschappen, 2005).

${ }^{44}$ Kees Zandvliet, Mapping for Money: Maps, Plans and Topographic Paintings and Their Role in Dutch Overseas Expansion during the 16th and 17th Centuries (Amsterdam: Batavian Lion Inter- 
national, 1998), 139; Van Oers, Dutch Town Planning, 78-79; Remco Raben, “Klein Holland," 48. ${ }^{45}$ This contrasts with most European cities designed for military defense in Stevin's period, which tended to be more circular, such as the contemporary nine-bastioned star-shaped Palmanova outside of Venice. Kostof, City Shaped, 160ff.

46 "Because in pentagonal and polygonal Cities, even if they are round with a convenient market in the centre and streets running up to the bulwarks, everything in a symmetrical order, however, many houses, blocks and plots become irregular and wider to one end than to the other." Stevin, Materiae Politicae, 17, quoted and translated in Van Oers, Dutch Town Planning, 83.

${ }^{47}$ The right angles of this canal at the corners were ill-advised--water does not flow as easily at a corner and this would prove a problem with Batavia's canals. See F. de Haan, Oud Batavia (Batavia: G. Kolff \& Co., 1922), 1:254.

${ }^{48}$ Van Oers points out four specifically Dutch features of this plan: the integrative role of water, the centrality of trade rather than the royal house, the attention to social and public functions, and religious tolerance as shown by the five church plots (the central one would belong to the state religion, but the other four could be purposed as befitted the population). Van Oers, Dutch Town Planning, 81-87.

${ }^{49}$ Van Oers, Dutch Town Planning, 83n29. Hierarchy is an aspect that Ron van Oers downplays in his analysis, including it as a subargument to his larger point about the importance of water control for this city.

${ }^{50}$ Van Oers, Dutch Town Planning, 83.

${ }^{51}$ On surveillance and the built environment, see Anna Vemer Andrzejewski, Building Power: Architecture and Surveillance in Victorian America (Knoxville: University of Tennessee Press, 2008), chapter 1.

${ }^{52}$ Van den Heuvel specifically disputes Ron van Oers's thesis that Stevin's plan was the basis for Batavia's layout, focusing instead on the earlier development of the grid in polder planning. He offers this hypothesis, which he describes as two layered grids (Van den Heuvel, "Multilayered Grids," 39), as an alternative source for the grid of Dutch cities abroad, countering Van Oers's reliance on Stevin's ideal plan. He argues further that the primary concern of the grid in its military application is flexibility in relation to the landscape and the temporality of the arrangement, which is useful for understanding the development of colonial cities.

${ }^{53}$ Van den Heuvel, "Multilayered Grids," 33-35.

${ }^{54}$ In the 1611 expansion of Leiden, to take one of Van den Heuvel's examples, the preexisting waterways appear to have determined the grid format. Van den Heuvel, "Multilayered Grids", 31. ${ }^{55}$ Simon Stevin, Castrametatio. Dat is Legermeting (Rotterdam: J. van Waesberghe, 1617). Pages 32 and 33, with the diagram, are reproduced in Van den Heuvel, "Multilayered Grids," 39. Van den Heuvel additionally notes (37) that Stevin's instruction took into account marshy landscape for plotting the camp's outline, a feature shared with the locations chosen for overseas settlements, always near a coastline and ideally also a river.

${ }^{56}$ Spiro Kostof criticizes E. A. Gutkind's interpretation of the Dutch grid as representing "Calvinist dogmatism and democratic equalitarianism," suggesting instead that it shows a "pragmatic bourgeois mercantilist culture." Kostof, City Shaped, 100. On the grander aesthetic concerns of the capital city of the Republic, see Rebecca Tucker, "Urban Planning and Politics in the City Center: Frederik Hendrik and The Hague Plein," Journal of Historians of Netherlandish Art 5, no. 2 (2013); www.jhna.org/. Accessed December 20, 2013.

${ }^{57}$ Higgins, Grid, 50. 
${ }^{58}$ Dell Upton, Another City: Urban Life and Urban Spaces in the New American Republic (New Haven: Yale University Press, 2008), chapter 6, esp. 122.

${ }^{59}$ Dell Upton, Another City, 261.

${ }^{60}$ Jaap Evert Abrahamse, De Grote Uitleg van Amsterdam: Stadsontwikkeling in de zeventiende eeuw (Bussum: Thoth, 2010).

${ }^{61}$ Fred Feddes, A Millennium of Amsterdam: Spatial History of a Marvellous City (Bussum: Thoth, 2012), 86; and Abrahamse, De Grote Uitleg, 75-77 and 351.

${ }^{62}$ Anthony D. King, Colonial Urban Development: Culture, Social Power, and Environment (London: Routledge \& Kegan Paul, 1976), 14, 25. Yeoh, Contesting Space, 2, expands on this binary population division.

${ }^{63}$ See Lance Castles, “The Ethnic Profile of Djakarta," Indonesia 3 (April 1967): 153-62. This account also contains an interesting explanation about the shifting profile of the group designated "Indonesian."

${ }^{64}$ Abeyasekere, Jakarta, 19-20.

${ }^{65}$ On the diversity of interests within this group, see Eric Tagliacozzo, "Navigating Communities: Race, Place, and Travel in the History of Maritime Southeast Asia," Asian Ethnicity 10, no. 2 (June 2009): 108-9.

${ }^{66}$ The status of this group as employees of the VOC makes their role in the imperial mission somewhat ambiguous--they are both working in the interest of the company and being shaped by the company's wishes, not quite a colonizing or colonized group. See Bhabha on the ambivalence of this position: Homi Bhabha, "Of Mimicry and Man: The Ambivalence of Colonial Discourse," in Tensions of Empire: Colonial Cultures in a Bourgeois World, ed. Frederick Cooper and Ann Laura Stoler (Berkeley: University of California Press, 1997), 152-60.

${ }^{67}$ When a Dutch man married an Asian woman legally, she and their children became Dutch citizens, though they were restricted from relocating to the Dutch Republic. Taylor, Social World, 17. Also note that despite the divisions introduced in the Asian populations of the city, Dutchmen drew their wives from all different quarters.

${ }^{68}$ Ann Laura Stoler, "Sexual Affronts and Racial Frontiers: European Identities and the Cultural Politics of Exclusion in Colonial Southeast Asia," in Tensions of Empire, ed. Cooper and Stoler, 199-201. See also Ann Laura Stoler, "Making Empire Respectable: The Politics of Race and Sexual Morality in $20^{\text {th }}$-Century Colonial Cultures," in Imperial Monkey Business: Racial Supremacy in Social Darwinist Theory and Colonial Practice, ed. Jan Breman et al., CASA Monograph 3 (Amsterdam: UV University Press, 1990), 35-70.

${ }^{69}$ Taylor, Social World, 45. See also Stoler, "Sexual Affronts."

${ }^{70}$ C. R. Boxer, Dutch Seaborne Empire, 89.

${ }^{71}$ Abeyasekere, Jakarta, 20; For the social status of soldiers and sailors, see A. Th. van Deursen, Plain Lives in a Golden Age: Popular Culture, Religion, and Society in Seventeenth-Century Holland, trans. Maarten Ultee (Cambridge: Cambridge University Press, 1991), 21-31, 200-204.

${ }^{72}$ Abeyesekere, Jakarta, 13. Taylor also provides a number of anecdotes about the undesirables in the Dutch population: Taylor, Social World, chapter 2.

${ }^{73}$ Indeed, many Dutch Batavians attained wealth only by violating the VOC monopoly, essentially, smuggling, so the financial support for ostentatious behavior was also gained by violating established Dutch custom. On smuggling, see Taylor, Social World, 33.

${ }^{74}$ This designation appears to refer to the Malabar Coast of India, and this group had come to Batavia through Portuguese enslavement by way of Malacca. See James Fox, "For Good and 
Sufficient Reasons': An Examination of Early Dutch East India Company Ordinances on Slaves and Slavery," in Slavery, Bondage, and Dependency in Southeast Asia, ed. Anthony Reid (St. Lucia: University of Queensland Press, 1983), 249.

${ }^{75}$ De Haan, Oud Batavia, 1:263.

${ }^{76}$ De Haan, Oud Batavia, 1:264.

${ }_{77}$ De Haan, Oud Batavia, 1:350-51.

${ }^{78}$ De Haan, Oud Batavia, 1:221.

${ }^{79}$ De Haan, Oud Batavia, 1:265, 361. "Moor" in Batavia refers to South Indian Muslims: Castles, "Ethnic Profile," 155.

${ }^{80}$ De Haan, Oud Batavia, 1: 351, 360.

${ }^{81}$ De Haan, Oud Batavia, 1: 245, 351-52.

${ }^{82}$ On the 1719 regulations, see Van der Chijs, Plakaatboek, 4:136-37; for the 1754 regulations, Plakaatboek, 6:773-95.

${ }^{83}$ Van der Chijs, Plakaatboek, 4:333-36.

${ }^{84}$ In the legislation following the massacre, it is clear that the government of Batavia feared violence from the Chinese. The law of Nov. 11, 1740, forbade Chinese from living within the city walls, imposed a curfew, and also forbade the selling of homes within the walls to Chinese, Muslims, or non-Christians, extending the scope of the anti-Chinese legislation. Van der Chijs, Plakaatboek, 4:510-14.

85 This is labeled as such on many maps, as can be seen in Figure 7.

${ }^{86}$ European slavery in Asia is rarely discussed, in large part because it is perceived to be a less extreme and encompassing enslavement than the Atlantic slave trade. Pieter C. Emmer, De Nederlandse slavenhandel, 1500-1850 (Amsterdam: Arbeiderspers, 2003); and Boxer, Dutch Seaborne Empire, briefly mention Dutch slavery in the East, but the best sources are Marcus Vink, “The World's Oldest Trade': Dutch Slavery and Slave Trade in the Indian Ocean in the Seventeenth Century," Journal of World History 14, no. 2 (June 2003): 131-77; and Anthony Reid, ed., Slavery, Bondage, and Dependency in Southeast Asia (St. Lucia: University of Queensland Press, 1983), especially the essays by Abeyasekere and Fox; and Gert Oostindie and Bert Passman, "Dutch Attitudes towards Colonial Empires, Indigenous Cultures, and Slaves," Eighteenth-Century Studies 31, no. 3 (Spring 1998): 349-55, which discusses the Dutch intellectual (non)response to slavery. ${ }^{87}$ For the locations of the slaves, see De Haan, Oud Batavia, 1:221, 351-52.

${ }^{88}$ For information on who owned large amounts of household slaves, see Susan Abeyasekere, "Slaves in Batavia: Insights from a Slave Register," in Slavery, Bondage, and Dependency in Southeast Asia, ed. Anthony Reid (St. Lucia: University of Queensland Press, 1983), 296.

${ }^{89}$ James Fox, "For Good and Sufficient Reasons," 249. The dredging of silted canals claimed the lives of 16,000 of these chained workers, as they performed the labor of making the city Dutch with its ill-fated canals, doubly reinforcing their own low status. De Haan, Oud Batavia, 1:238. ${ }^{90}$ Fox “For Good and Sufficient Reasons," 251.

${ }^{91}$ Slaves were also required to walk alongside horses that they were transporting, rather than riding them. Fox "For Good and Sufficient Reasons," 257.

${ }^{92}$ For a thoughtful consideration of a similar differentiation in Virginia, see Dell Upton, "White and Black Landscapes in Eighteenth-Century Virginia," Places 2, no. 2 (1984): 59-72.

${ }^{93}$ Vink, “The World's Oldest Trade," 162. For example, slaves from Malacca were perceived to be excellent craftsmen, and slaves from Africa were thought of as strong miners.

${ }^{94}$ Fox “"For Good and Sufficient Reasons," 252-55.

\section{Bibliography}

Abeyasekere, Susan. "Slaves in Batavia: Insights from a Slave Register." In Slavery, Bondage, 
and Dependency in Southeast Asia, edited by Anthony Reid, 286-314. St. Lucia: University of Queensland Press, 1983.

Abeyasekere, Susan. Jakarta: A History. 2nd ed. Singapore/Oxford/New York: Oxford University Press, 1989.

Abrahamse, Jaap Evert. De Grote Uitleg van Amsterdam: Stadsontwikkeling in de zeventiende eeuw. Bussum: Thoth, 2010.

Andrzejewski, Anna Vemer. Building Power: Architecture and Surveillance in Victorian America. Knoxville: University of Tennessee Press, 2008.

Bhabha, Homi K. “The Other Question: Difference, Discrimination and the Discourse of Colonialism.” In Out There: Marginalization and Contemporary Cultures, edited by Russell Ferguson et al., 71-87. Cambridge, Mass.: MIT Press, 1990.

Bhabha, Homi. "Of Mimicry and Man: The Ambivalence of Colonial Discourse." In Tensions of Empire: Colonial Cultures in a Bourgeois World, edited by Frederick Cooper and Ann Laura Stoler, 152-60. Berkeley: University of California Press, 1997.

Blusse, Leonard. "An Insane Administration and an Unsanitary Town: The Dutch East India Company and Batavia (1619-1799)." In Colonial Cities, edited by Robert J. Ross and Gerard J. Telkamp, 65-86. Dordrecht: Martinus Nijhoff, 1985.

Boxer, C. R. The Dutch Seaborne Empire 1600-180.0 New York: Penguin Books, 1965.

Brug, Peter H. van der. "Unhealthy Batavia and the Decline of the VOC in the Eighteenth Century." In Jakarta/Batavia: Socio-Cultural Essays, edited by Kees Grijns and Peter J. M. Nas, 43-74. Leiden: KITLV Press, 2000.

Castles, Lance. “The Ethnic Profile of Djakarta.” Indonesia 3 (April 1967): 153-204.

Chattopadhyay, Swati. Representing Calcutta: Modernity, Nationalism, and the Colonial Uncanny. London: Routledge, 2005.

Chijs, Jacobus Anne van der. Nederlandsch-Indisch Plakaatboek. 17 vols. Batavia: Landsdrukkerij, 1885-1900.

Crouch, Dora P., Daniel J. Garr, and Axel I. Mundigo. Spanish City Planning in North America. Cambridge, Mass.: MIT Press, 1982).

Deursen, A. Th. van. Plain Lives in a Golden Age: Popular Culture, Religion, and Society in Seventeenth-Century Holland. Translated by Maarten Ultee. Cambridge: Cambridge University Press, 1991. 
Dijksterhuis, E. J. Simon Stevin: Science in the Netherlands around 1600. The Hague: Martinus Nijhoff, 1970.

Emmer, Pieter C. De Nederlandse slavenhandel, 1500-1850. Amsterdam: Arbeiderspers, 2003.

Feddes, Fred. A Millennium of Amsterdam: Spatial History of a Marvellous City. Bussum: Thoth, 2012.

Fox, James. “'For Good and Sufficient Reasons': An Examination of Early Dutch East India Company Ordinances on Slaves and Slavery." In Slavery, Bondage, and Dependency in Southeast Asia, edited by Anthony Reid, 246-62. St. Lucia: University of Queensland Press, 1983.

Fraser, Valerie. The Architecture of Conquest: Building in the Viceroyalty of Peru 1535-1635. Cambridge: Cambridge University Press, 1990.

Greer, Margaret R., Walter D. Mignolo, and Maureen Quilligan, eds. Rereading the Black Legend: The Discourses of Religious and Racial Difference in the Renaissance Empires. Chicago: University of Chicago Press, 2007.

Haan, F. de. Oud Batavia. 2 vols. and plate album. Batavia: G. Kolff \& Co., 1922.

Heuvel, Charles van den. "De Huysbou": A Reconstruction of an Unfinished Treatise on Architecture, Town Planning and Civil Engineering by Simon Stevin. Translated by D. Gardner. Amsterdam: Koninklijke Nederlandse Akademie van Wetenschappen, 2005

Heuvel, Charles van den. "Multilayered Grids and Dutch Town Planning: Flexibility and Temporality in the Design of Settlements in the Low Countries and Overseas." In Early Modern Urbanism and the Grid: Town Planning in the Low Countries in International Context; Exchanges in Theory and Practice 1550-1800, edited by P. Lombaerde and C. van den Heuvel, 27-44. Turnhout: Brepols, 2011.

Higgins, Hannah B. The Grid Book. Cambridge, Mass.: MIT Press, 2009.

Hochstrasser, Julie Berger. Still Life and Trade in the Dutch Golden Age New Haven: Yale University Press, 2007.

Israel, Jonathan. The Dutch Republic: Its Rise, Greatness, and Fall 1477-1806. Oxford: Clarendon Press, 1995.

Jacobs, Els M. In Pursuit of Pepper and Tea: The Story of the Dutch East India Company. Zutphen: Walberg Pers, 1991.

Jacobs, Els M. Koopman in Azië: De handel van de Verenigde Oost-Indische Compagnie tijdens de 18de eeuw. Zutphen: Walberg Pers, 2000. 
Keane, Webb. Signs of Recognition: Powers and Hazards of Representation in an Indonesian Society. Berkeley: University of California Press, 1997.

King, Anthony D. Colonial Urban Development: Culture, Social Power, and Environment. London: Routledge \& Kegan Paul, 1976.

Kniffen, Fred. "Folk Housing: Key to Diffusion." In Common Places: Readings in American Vernacular Architecture, edited by Dell Upton and John Michael Vlach, 3-26. Athens: University of Georgia Press, 1986.

Kostof, Spiro. The City Shaped: Urban Patterns and Meanings Through History. London: Thames and Hudson, 1991.

Leerssen, Joep. National Thought in Europe: A Cultural History. Amsterdam: Amsterdam University Press, 2006.

Markley, Robert. The Far East and the English Imagination, 1600-1730. Cambridge: Cambridge University Press, 2006.

Meilink-Roelofsz, M. A. P. Asian Trade and European Influence in the Indonesian Archipelago between 1500 and about 1630. The Hague: Martinus Nijhoff, 1962.

Moer, A. van der. Een zestiende-eeuwse Hollander in het Verre Oosten en het Hoge Noorden: Leven, werken, reizen en avonturen van Jan Huyghen van Linschoten (1563-1611). The Hague: Martinus Nijhoff, 1979.

Nieuhof, Johannes. Gedenkwaardige Brasiliaense zee- en landreis. Amsterdam: Widow of van Jacob van Meurs, 1682.

Odell, Dawn. "Public Identity and Material Culture in Dutch Batavia." In Crossing Cultures: Conflict, Migration, and Convergence; The Proceedings of the 32nd International Congress on the History of Art, The University of Melbourne, 13-18 January 2008, edited by Jaynie Anderson, 253-57. Carlton, Australia: Miegunyah Press, 2009.

Oers, Ron van. Dutch Town Planning Overseas During VOC and WIC Rule (1600-1800). Zutphen, Walberg Pers, 2000.

Oostindie, Gert, and Bert Passman. "Dutch Attitudes towards Colonial Empires, Indigenous Cultures, and Slaves." Eighteenth-Century Studies 31, no. 3 (Spring 1998): 349-55.

Raben, Remco. "Klein Holland in Azie: Ideologie en pragmatisme in de Nederlandse koloniale stedebouw, 1600-1800." Leidschrift 9, no. 2 (1993): 44-63.

Reid, Anthony, ed. Slavery, Bondage, and Dependency in Southeast Asia. St. Lucia: University of Queensland Press, 1983. 
Reid, Anthony. Southeast Asia in the Age of Commerce 1450-1680. 2 vols. New Haven: Yale University Press, 1988 and 1993.

Rupert, Linda M. Creolization and Contraband: Curaçao in the Early Modern Atlantic World. Athens: University of Georgia Press, 2012.

Schama, Simon. The Embarrassment of Riches: An Interpretation of Dutch Culture in the Golden Age. New York: Vintage, 1987.

Schmidt, Benjamin. Innocence Abroad: The Dutch Imagination and the New World, 1570-1670. Cambridge: Cambridge University Press, 2001.

Stevin, Simon. Castrametatio. Dat is Legermeting. Rotterdam: J. van Waesberghe, 1617.

Stevin, Simon. Materiae Politicae. Bvrgherlicke Stoffen: vervanghende ghedachtenissen der oeffeninghen des doorluchtichsten Prince Maurits van Orangie. Leiden: Justus Livius, 1650.

Stevin, Simon. Principal Works. 5 vols. Edited by Ernst Crone.Translated C. Dikshoorn. Amsterdam: C. V. Swets \& Zeitlinger, 1955-66.

Stoler, Ann Laura. "Making Empire Respectable: The Politics of Race and Sexual Morality in 20th Century Colonial Cultures." In Imperial Monkey Business: Racial Supremacy in Social Darwinist Theory and Colonial Practice, edited by Jan Breman et al., 35-70. CASA Monograph 3. Amsterdam: UV University Press, 1990.

Stoler, Ann Laura. "Sexual Affronts and Racial Frontiers: European Identities and the Cultural Politics of Exclusion in Colonial Southeast Asia." In Tensions of Empire: Colonial Cultures in a Bourgeois World, edited by Frederick Cooper and Ann Laura Stoler, 198-237. Berkeley: University of California Press, 1997.

Sutton, Elizabeth. "Possessing Brazil in Print, 1630-1654." Journal of Historians of Netherlandish Art 5, no. 1 (2013). www.jhna.org/. Accessed September 2, 2013.

Tagliacozzo, Eric. "Navigating Communities: Race, Place, and Travel in the History of Maritime Southeast Asia." Asian Ethnicity 10, no. 2 (June 2009): 97-120.

Taylor, Jean Gelman. The Social World of Batavia: European and Eurasian in Dutch Asia. Madison: University of Wisconsin Press, 1983.

Temminck Groll, C. L., ed. The Dutch Overseas: Architectural Survey; Mutual Heritage of Four Centuries in Three Continents. Zwolle: Waanders, 2002.

Tucker, Rebecca. "Urban Planning and Politics in the City Center: Frederik Hendrik and The Hague Plein." Journal of Historians of Netherlandish Art 5, no. 2 (2013). www.jhna.org/. Accessed 
December 20, 2013.

Upton, Dell. "White and Black Landscapes in Eighteenth-Century Virginia." Places 2, no. 2 (1984): 59-72.

Upton, Dell. Another City: Urban Life and Urban Spaces in the New American Republic. New Haven: Yale University Press, 2008.

Valentijn, François. Oud en nieuw Oost-Indiën. 5 vols. Dordrecht and Amsterdam: Joannes van Braam and Gerard Onder de Linden, 1724-26.

Vink, Marcus. “The World's Oldest Trade': Dutch Slavery and Slave Trade in the Indian Ocean in the Seventeenth Century." Journal of World History 14, no. 2 (June 2003): 131-77.

Vries, Jan de and Ad van der Woude. The First Modern Economy: Success, Failure, and Perseverance of the Dutch Economy, 1500-1815. Cambridge: Cambridge University Press, 1997.

Yeoh, Brenda S. A. Contesting Space: Power Relations and the Urban Built Environment in Colonial Singapore. Kuala Lumpur: Oxford University Press, 1996.

Zandvliet, Kees. Mapping for Money: Maps, Plans and Topographic Paintings and Their Role in Dutch Overseas Expansion during the 16th and 17th Centuries. Amsterdam: Batavian Lion International, 1998.

Zandvliet, Kees, ed. The Dutch Encounter with Asia: 1600-1950. Zwolle: Waanders and Rijksmuseum Amsterdam, 2002).

\section{Reccommended Citation:}

